Supplement of Atmos. Chem. Phys., 15, 5457-5469, 2015

http://www.atmos-chem-phys.net/15/5457/2015/

doi:10.5194/acp-15-5457-2015-supplement

(C) Author(s) 2015. CC Attribution 3.0 License.

(c) (i)

\title{
Free amino acids in Antarctic aerosol: potential markers for the evolution and fate of marine aerosol
}

\section{E. Barbaro et al.}

Correspondence to: E. Barbaro (barbaro@unive.it)

The copyright of individual parts of the supplement might differ from the CC-BY 3.0 licence. 


\section{Reagents and standard solutions}

Ultra grade methanol (MeOH) was purchased from Romil LTD (Cambridge, UK), while Ultrapure water (18.2 M $\Omega, 0.01$ TOC) was produced using a Purelab Ultra System (Elga, High Wycombe,UK). Formic acid ( $\geq 98 \%)$ eluent additive for HPLC system was obtained from Fluka (Sigma Aldrich®, Buchs, Switzerland) and hydrochloric acid (HCl) 37\% ACS was supplied by Carlo Erba.

Each amino acid standard solution (D and L-alanine (D-/L-Ala), D and L-arginine (D-/L-Arg), D and L - asparagine (D-/L-Asn), D and L-aspartic acid (D-/L-Asp), D and L -glutamic acid (D-/LGlu), glycine (Gly), D and L hydroxy proline (D-/L-Hyp), D and L -histidine (D-/L-Hys), D and L -isoleucine (D-/L-Ile), D and L - leucine (D-/L-Leu),D and L -methionine (D-/L-Met), D/L methionine sulfone $\left(\mathrm{MetSO}_{2}\right.$ ), L ornithine (L-Orn), D and L -phenylalanine (D-/L-Phe), L-proline (L-Pro), D and L -serine (D-/L-Ser), D and L -threonine (D-/L-Thr), D and L -tyrosine (D-/L-Tyr), $\mathrm{D}$ and $\mathrm{L}$ tryptophan (D-/L-Trp), and D and L - valine(D-/L-Val)) was prepared from a solid standard (purity $\geq 98 \%$ ), and diluted in $\mathrm{HCl} 0.1 \mathrm{M}$. The solid standards were purchased from Sigma Aldrich®. Isotopically-labeled $13 \mathrm{C}$ amino acids $\left(\mathrm{L}-\left[{ }^{13} \mathrm{C}_{3}\right]\right.$ alanine (Ala*), L- $\left[{ }^{13} \mathrm{C}_{4}\right]$ aspartic acid (Asp*), L$\left[{ }^{13} \mathrm{C}_{5}\right]$ glutamic acid $\left(\mathrm{Glu}^{*}\right)$, and L- $\left[{ }^{13} \mathrm{C}_{6}\right]$ arginine (Arg*); purity of $98 \%$ ) were purchased from Sigma Aldrich while L- $\left[{ }^{13} \mathrm{C}_{1}\right]$ leucine $\left(\mathrm{Leu}^{*}\right)$, L- $\left[{ }^{13} \mathrm{C}_{1}\right]$ phenylalanine (Phe*), L- $\left[{ }^{13} \mathrm{C}_{1}\right]$ proline (Pro*), and $\mathrm{L}-\left[{ }^{13} \mathrm{C}_{1}\right]$ valine $\left(\mathrm{Val}^{*}\right)$ (purity $\geq 98 \%$ ) were obtained from Cambridge Isotope Laboratories Inc. (Andover, MA). 
Table S1. Summary of yield, trueness and reproducibility expressed as a relative standard deviation (RSD\%) for circular quartz fiber filters. For each amino acid, the internal standard (IS) used for the quantification, the amount of blank filter and the relative method detection limit (MDL)is reported.

\begin{tabular}{|c|c|c|c|c|c|c|c|}
\hline & IS & $\begin{array}{c}\text { Yield } \\
\%\end{array}$ & $\begin{array}{c}\text { RSD } \\
\%\end{array}$ & $\begin{array}{c}\text { Error } \\
\%\end{array}$ & $\begin{array}{c}\text { RSD } \\
\%\end{array}$ & $\begin{array}{c}\text { Blank } \\
\text { (ng abs) }\end{array}$ & $\begin{array}{c}\text { MDL } \\
\text { (ng abs) }\end{array}$ \\
\hline L-Ala & Ala* & 51 & 10 & -10 & 2 & 151 & 44 \\
\hline D-Ala & Ala* & 62 & 7 & 4 & 3 & 30 & 22 \\
\hline L-Arg & Arg* & 62 & 8 & -2 & 9 & 4 & 2 \\
\hline D-Arg & Arg* & 78 & 2 & 0.7 & 1 & 4 & 3.2 \\
\hline L-Asn & $\mathrm{Val}^{*}$ & 70 & 9 & 3 & 7 & 10 & 6 \\
\hline D-Asn & $\mathrm{Val}^{*}$ & 67 & 2 & -4 & 9 & 15 & 6 \\
\hline L-Asp & Asp* & 50 & 8 & -7 & 6 & 41 & 30 \\
\hline D-Asp & Asp* & 41 & 8 & 2 & 13 & 102 & 50 \\
\hline L-Glu & Glu* & 58 & 7 & -6 & 2 & 25 & 6 \\
\hline D-Glu & Glu* & 57 & 9 & -1 & 6 & 12 & 8 \\
\hline L-Hyp & Leu* & 70 & 9 & 7 & 13 & 0.2 & 0.5 \\
\hline D-Hyp & Leu* & 74 & 7 & -5 & 10 & 1 & 1.4 \\
\hline L-Hys & Pro* & 66 & 9 & 6 & 1 & 51 & 16 \\
\hline D-Hys & Pro* & 49 & 7 & -8 & 8 & 7 & 10 \\
\hline L-Leu/L-Ile & Leu* & 60 & 5 & -7 & 6 & 77 & 32 \\
\hline D-Leu/D-Ile & Leu* & 59 & 5 & -13 & 6 & 3 & 5.8 \\
\hline L-Met & Leu* & 61 & 11 & -2 & 8 & 2 & 3.2 \\
\hline D-Met & Leu* & 65 & 9 & -9 & 3 & 8 & 10 \\
\hline L-Orn & Arg* & 43 & 13 & 2 & 14 & 249 & 58 \\
\hline L-Phe & Phe* & 63 & 5 & -3 & 4 & 5 & 2.8 \\
\hline D-Phe & Phe* & 70 & 4 & 7 & 9 & 6 & 5.8 \\
\hline L-Pro & Pro* & 61 & 9 & -4 & 3 & 15 & 3.8 \\
\hline L-Ser & Phe* & 38 & 17 & -2 & 8 & 170 & 138 \\
\hline D-Ser & Phe* & 56 & 15 & 6 & 13 & 98 & 84 \\
\hline L-Thr & Arg* & 65 & 6 & -1 & 5 & 10 & 5 \\
\hline D-Thr & Arg* & 72 & 6 & 5 & 6 & 2 & 1 \\
\hline L-Trp & Arg* & 63 & 10 & 5 & 6 & 2 & 5 \\
\hline D-Trp & Arg* & 65 & 10 & -0.2 & 9 & 1 & 1.2 \\
\hline L-Tyr & Phe* & 66 & 13 & 8 & 10 & 24 & 16 \\
\hline D-Tyr & Phe* & 67 & 9 & 7 & 10 & 6 & 8 \\
\hline L-Val & $\mathrm{Val}^{*}$ & 61 & 6 & -6 & 2 & 57 & 12 \\
\hline D-Val & $\mathrm{Val}^{*}$ & 64 & 10 & -5 & 5 & 6 & 3 \\
\hline Gly & Ala* & 71 & 11 & 3 & 4 & 89 & 50 \\
\hline MetSO2 & Leu* & 58 & 8 & -5 & 8 & 8 & 14 \\
\hline
\end{tabular}


Table S2. Summary of yield, trueness and reproducibility expressed as relative standard deviation (RSD\%) for backup quartz fiber filters $(<0.49 \mu \mathrm{m})$. For each amino acid, the internal standard (IS) used for the quantification, the amount of blank filter and the relative method detection limit (MDL) is reported.

\begin{tabular}{|c|c|c|c|c|c|c|c|}
\hline & IS & $\begin{array}{c}\text { Yield } \\
\%\end{array}$ & $\begin{array}{c}\text { RSD } \\
\%\end{array}$ & $\begin{array}{c}\text { Error } \\
\%\end{array}$ & $\begin{array}{c}\text { RSD } \\
\%\end{array}$ & $\begin{array}{c}\text { Blank } \\
\text { (ng abs) }\end{array}$ & $\begin{array}{c}\text { MDL } \\
\text { (ng abs) }\end{array}$ \\
\hline L-Ala & Ala* & 51 & 6 & -8 & 3 & 226 & 35 \\
\hline D-Ala & Ala* & 61 & 9 & 9 & 7 & 67 & 36 \\
\hline L-Arg & Arg* & 53 & 7 & -7 & 2 & 26 & 24 \\
\hline D-Arg & Arg* & 61 & 8 & 8 & 3 & 4 & 3 \\
\hline L-Asn & $\mathrm{Val}^{*}$ & 55 & 6 & -2 & 6 & 45 & 28 \\
\hline D-Asn & $\mathrm{Val}^{*}$ & 54 & 9 & 6 & 9 & 30 & 28 \\
\hline L-Asp & Asp* & 54 & 6 & -2 & 4 & 125 & 35 \\
\hline D-Asp & Asp* & 54 & 9 & 1 & 8 & 51 & 28 \\
\hline L-Glu & Glu* & 54 & 5 & -3 & 4 & 99 & 18 \\
\hline D-Glu & Glu* & 50 & 9 & 5 & 7 & 16 & 8 \\
\hline L-Hyp & $\mathrm{Val}^{*}$ & 56 & 8 & 3 & 10 & 3 & 4 \\
\hline D-Нyp & $\mathrm{Val}^{*}$ & 70 & 8 & 7 & 7 & 4 & 5 \\
\hline L-Hys & Pro* & 57 & 32 & 77 & 15 & 88 & 114 \\
\hline D-Hys & Pro* & 46 & 16 & -21 & 10 & 43 & 64 \\
\hline L-Leu/L-Ile & Leu* & 57 & 3 & -8 & 9 & 31 & 23 \\
\hline D-Leu/D-Ile & Leu* & 61 & 9 & -4 & 2 & 14 & 12 \\
\hline L-Met & Leu* & 56 & 9 & -9 & 5 & 20 & 19 \\
\hline D-Met & Leu* & 51 & 5 & -9 & 2 & 11 & 6 \\
\hline L-Orn & Arg* & 42 & 5 & -3 & 8 & 275 & 61 \\
\hline L-Phe & Phe* & 60 & 7 & 1 & 6 & 32 & 11 \\
\hline D-Phe & Phe* & 65 & 9 & 4 & 8 & 3 & 2 \\
\hline L-Pro & Pro* & 55 & 5 & -4 & 3 & 73 & 42 \\
\hline L-Ser & Phe* & 55 & 7 & 8 & 5 & 597 & 167 \\
\hline D-Ser & Phe* & 42 & 9 & -6 & 5 & 422 & 61 \\
\hline L-Thr & Arg* & 63 & 10 & 9 & 1 & 46 & 18 \\
\hline D-Thr & Arg* & 58 & 5 & 7 & 3 & 12 & 9 \\
\hline L-Trp & Phe* & 63 & 9 & -5 & 7 & 3 & 4 \\
\hline D-Trp & Phe* & 61 & 9 & -1 & 9 & 7 & 10 \\
\hline L-Tyr & Phe* & 53 & 6 & 2 & 7 & 30 & 34 \\
\hline D-Tyr & Phe* & 62 & 11 & 7 & 8 & 10 & 8 \\
\hline L-Val & $\mathrm{Val}^{*}$ & 58 & 6 & -3 & 2 & 91 & 49 \\
\hline D-Val & $\mathrm{Val}^{*}$ & 50 & 8 & -7 & 8 & 5 & 12 \\
\hline Gly & Ala* & 56 & 6 & -1 & 3 & 61 & 37 \\
\hline MetSO2 & Leu* & 51 & 9 & -9 & 8 & 32 & 23 \\
\hline
\end{tabular}


Table S3. Summary of yield, trueness and reproducibility expressed as relative standard deviation (RSD\%) for slotted quartz fiber filters. For each amino acid, the internal standard (IS) used for the quantification the amount of blank filter and the relative method detection limit (MDL) is reported.

\begin{tabular}{|c|c|c|c|c|c|c|c|}
\hline & IS & $\begin{array}{c}\text { Yield } \\
\%\end{array}$ & $\begin{array}{c}\text { RSD } \\
\%\end{array}$ & $\begin{array}{c}\text { Error } \\
\%\end{array}$ & $\begin{array}{c}\text { RSD } \\
\%\end{array}$ & $\begin{array}{c}\text { Blank } \\
\text { (ng abs) }\end{array}$ & $\begin{array}{c}\text { MDL } \\
\text { (ng abs) }\end{array}$ \\
\hline L-Ala & Ala* & 72 & 6 & -6 & 5 & 57 & 24 \\
\hline D-Ala & Ala* & 346 & 6 & 450 & 7 & - & - \\
\hline L-Arg & Arg* & 51 & 7 & -9 & 4 & 8 & 4 \\
\hline D-Arg & Arg* & 53 & 3 & -1 & 6 & 2 & 1 \\
\hline L-Asn & Val* & 32 & 5 & -64 & 5 & 0.2 & 0.2 \\
\hline D-Asn & Val* & 190 & 7 & 191 & 9 & - & - \\
\hline L-Asp & Asp* & 71 & 6 & 1 & 3 & 102 & 51 \\
\hline D-Asp & Asp* & 37 & 26 & -3 & 33 & 348 & 107 \\
\hline L-Glu & Glu* & 81 & 2 & 7 & 4 & 0.6 & 1.1 \\
\hline D-Glu & Glu* & 494 & 10 & 799 & 9 & - & - \\
\hline L-Hyp & Leu* & 81 & 4 & 3 & 5 & 0.5 & 0.2 \\
\hline D-Hyp & Leu & 75 & 5 & -8 & 5 & 0.5 & 0.8 \\
\hline L-Hys & Leu* & 71 & 9 & 1 & 15 & 3 & 3 \\
\hline D-Hys & Asp* & 45 & 8 & -5 & 14 & 12 & 9 \\
\hline L-Leu/L-Ile & Leu* & 5 & 65 & 7 & -9 & 9 & 7 \\
\hline D-Leu/D-Ile & Leu* & 7 & 72 & 13 & -6 & 10 & 8 \\
\hline L-Met & Leu* & 61 & 10 & -8 & 11 & 5 & 4 \\
\hline D-Met & Leu* & 50 & 8 & -2 & 8 & 2.1 & 0.5 \\
\hline L-Orn & Arg* & 50 & 9 & 4 & 8 & 41 & 23 \\
\hline L-Phe & Phe* & 77 & 3 & -2 & 3 & 12 & 10 \\
\hline D-Phe & Phe* & 102 & 9 & 56 & 4 & - & - \\
\hline L-Pro & Pro* & 61 & 7 & -8 & 5 & 82 & 56 \\
\hline L-Ser & Phe* & 88 & 10 & 57 & 7 & - & - \\
\hline D-Ser & Phe* & -18 & -6 & -115 & -40 & - & - \\
\hline L-Thr & Arg* & 57 & 6 & -9 & 7 & 19 & 8 \\
\hline D-Thr & Arg* & 64 & 8 & 7 & 4 & 3 & 2 \\
\hline L-Trp & Phe* & 99 & 8 & 59 & 10 & - & - \\
\hline D-Trp & Phe* & 93 & 6 & 54 & 11 & - & - \\
\hline L-Tyr & Arg* & 61 & 4 & 6 & 4 & 12 & 16 \\
\hline D-Tyr & Arg* & 63 & 7 & -13 & 13 & 4 & 7 \\
\hline L-Val & Val* & 78 & 3 & -3 & 3 & 23 & 12 \\
\hline D-Val & Val* & 174 & 8 & 140 & 7 & - & - \\
\hline Gly & Ala* & 36 & 41 & -7 & 3 & 36 & 15 \\
\hline MetSO2 & Leu* & 66 & 5 & -9 & 5 & & 4 \\
\hline
\end{tabular}



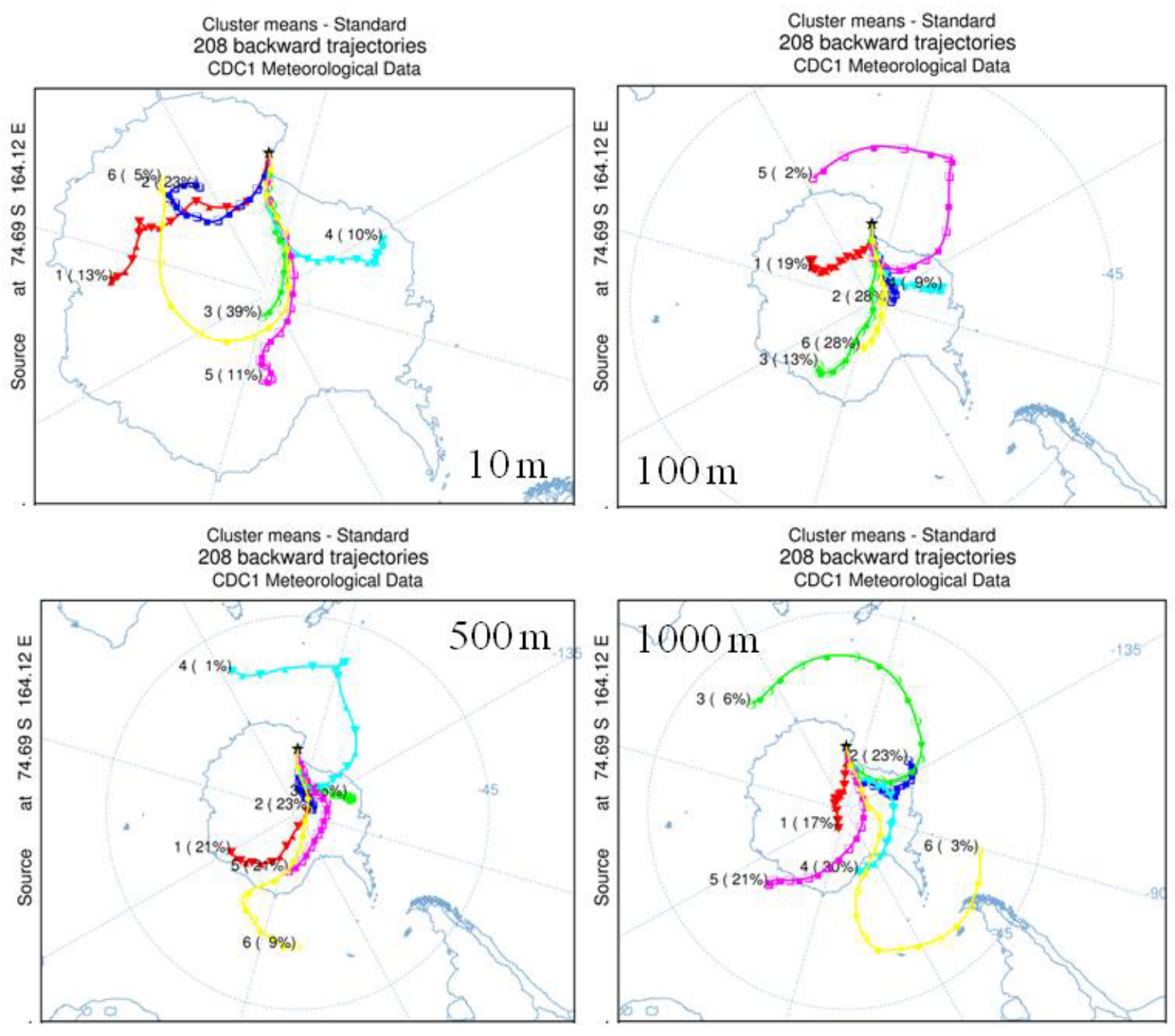

Figure S1. Cluster means backward trajectories analyses at $10 \mathrm{~m}, 100 \mathrm{~m}, 500 \mathrm{~m}$ and $1000 \mathrm{~m}$ agl at the coastal base "Mario Zucchelli Station" (MZS) during the summer of 2010-2011. Study of the vertical stability of HYSPLIT model. The 208 back trajectories are divided into 6 clusters with the percentage of total number of trajectories that each represents reported in brackets. 

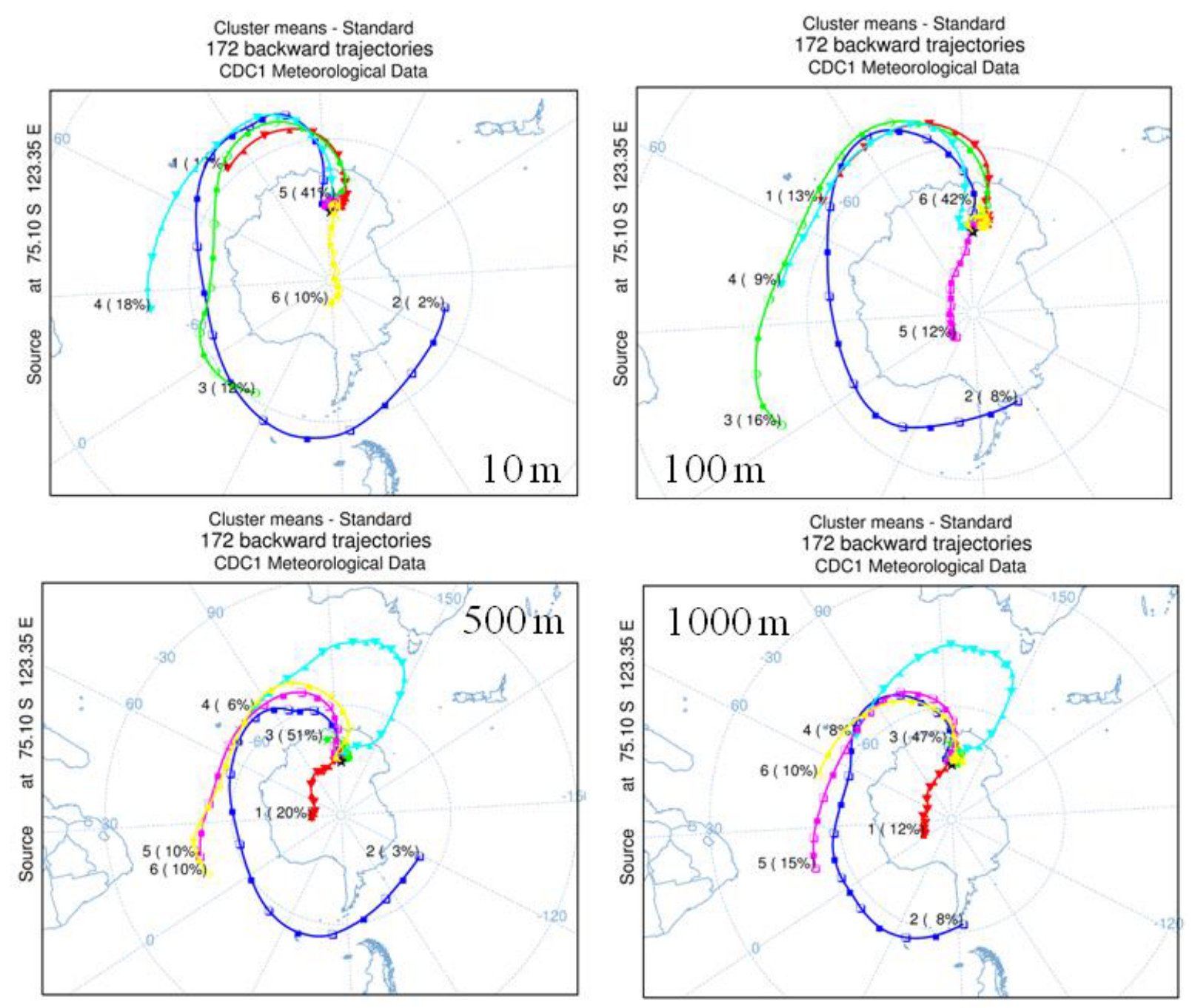

Figure S2. Cluster means backward trajectories analyses at $10 \mathrm{~m}, 100 \mathrm{~m}, 500 \mathrm{~m}$ and $1000 \mathrm{~m}$ agl at the Italian-French base Dome C (DC) during the summers of 2011-2012. Study of the vertical stability of HYSPLIT model. The 172 back trajectories are divided into 6 clusters with the percentage of total number of trajectories that each represents reported in brackets. 


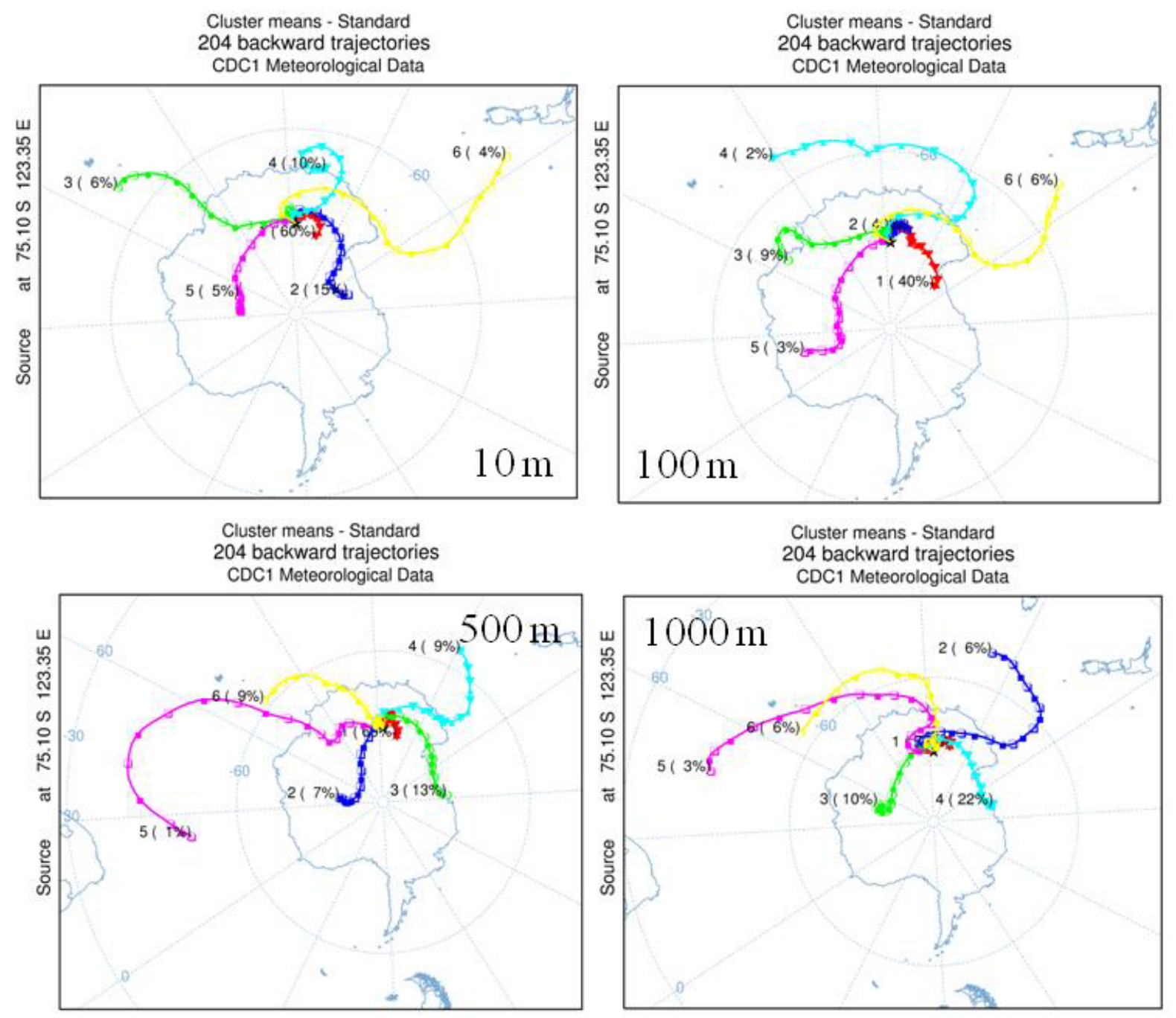

Figure3. Cluster means backward trajectories analyses at $10 \mathrm{~m}, 100 \mathrm{~m}, 500 \mathrm{~m}$ and $1000 \mathrm{~m}$ agl at the Italian-French base Dome C (DC) during the summers of 2012-2013. Study of the vertical stability of HYSPLIT model. The 204 back trajectories are divided into 6 clusters with the percentage of total number of trajectories that each represents reported in brackets. 

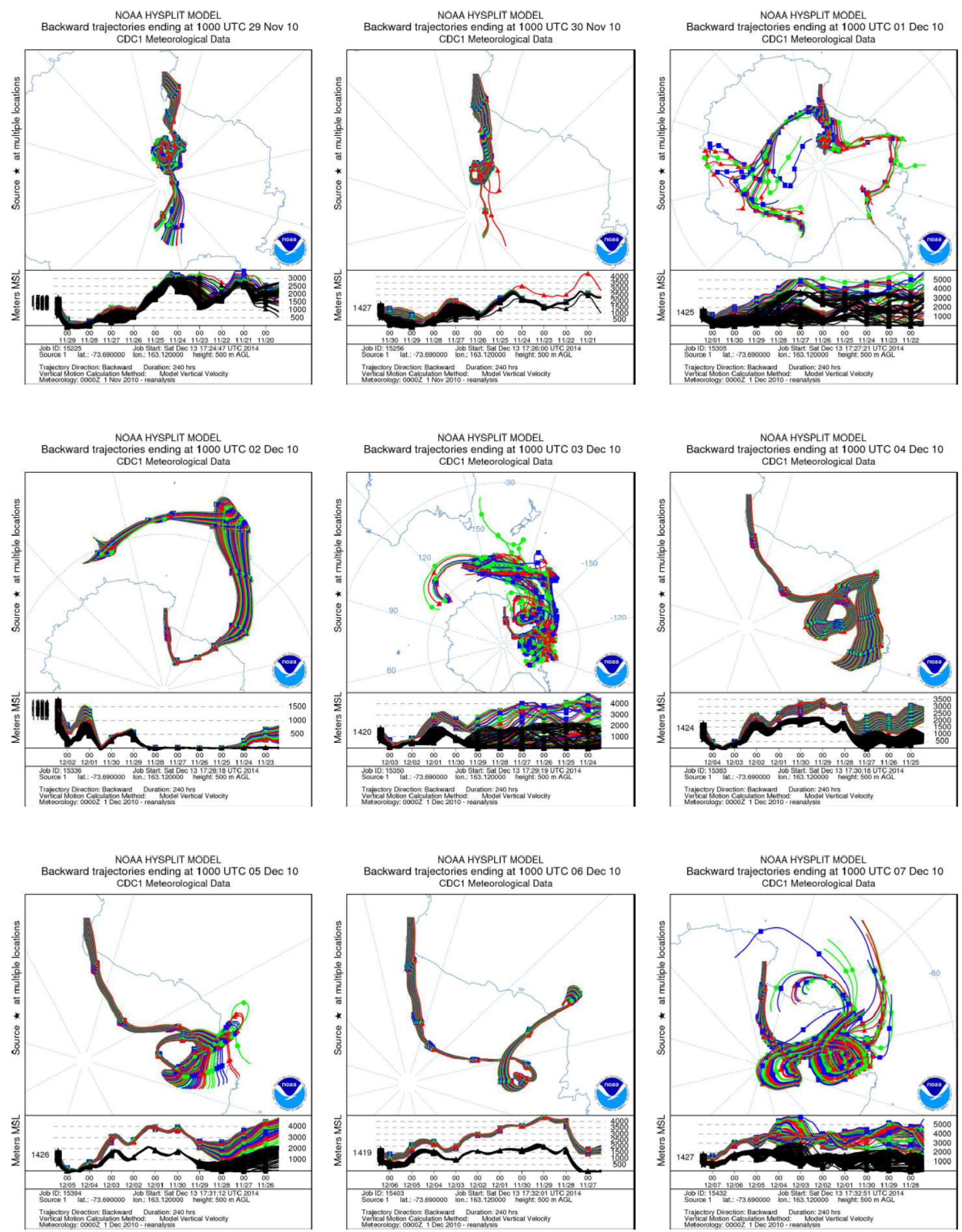

Figure S4. Matrix back-trajectories computed for each 24-h sampling at $500 \mathrm{~m}$ agl at the coastal base "Mario Zucchelli Station" (MZS) from the $29^{\text {th }}$ November 2010 to $18^{\text {th }}$ January 2011. Study of the horizontal stability of HYSPLIT model varying the source position of one degree of latitude and longitude from the real coordinates of source. 

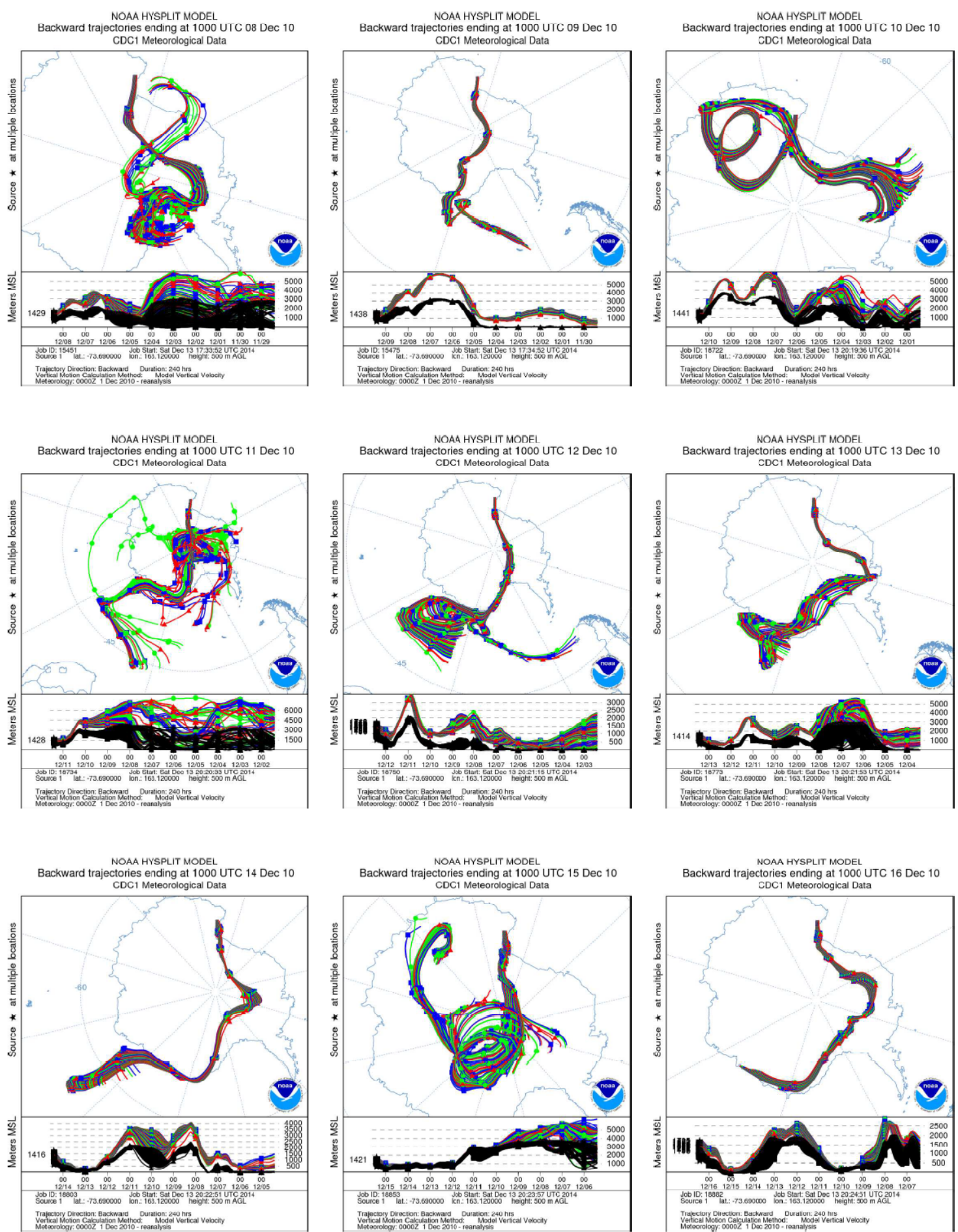

Figure S4. continued 

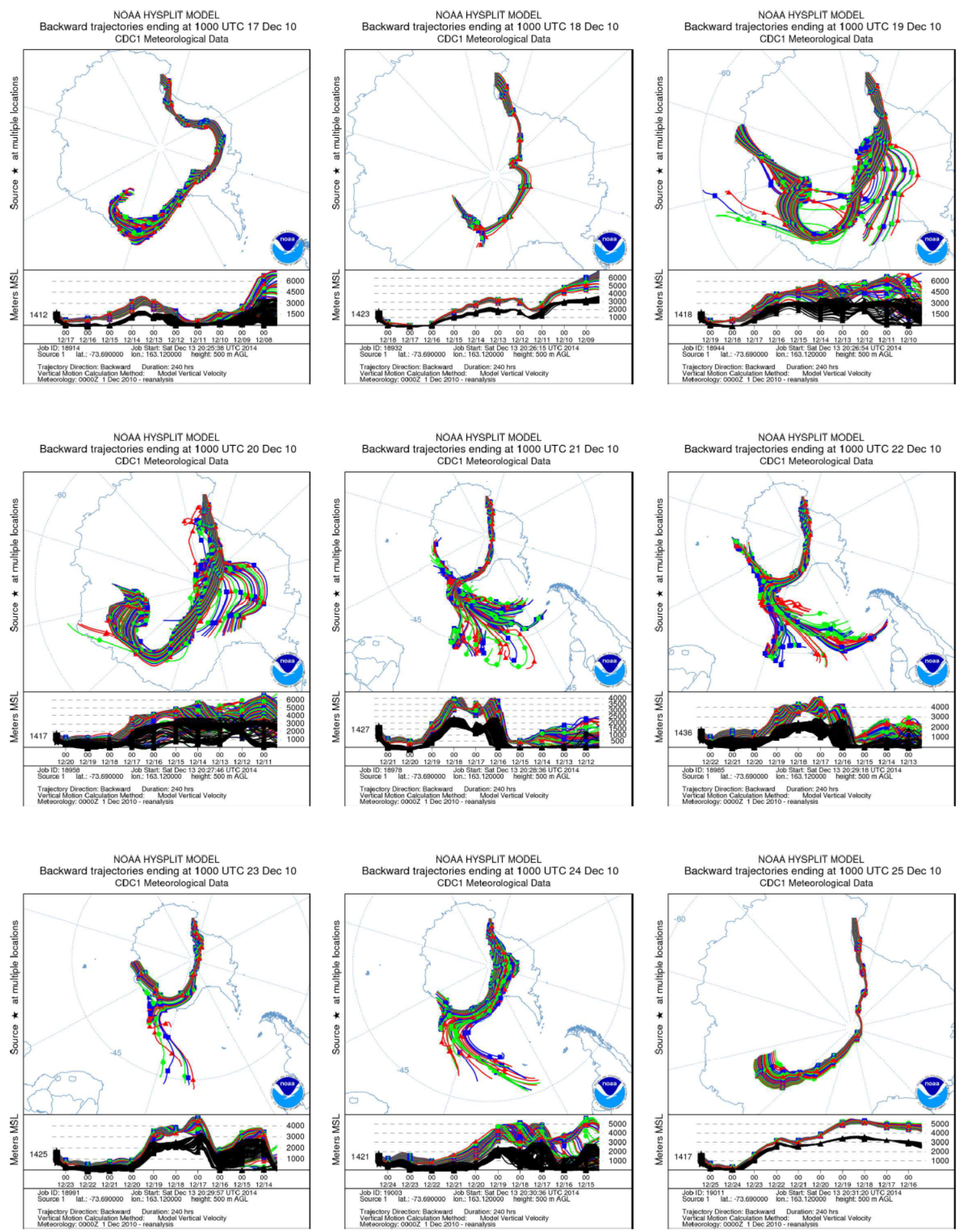

Figure S4. continued 

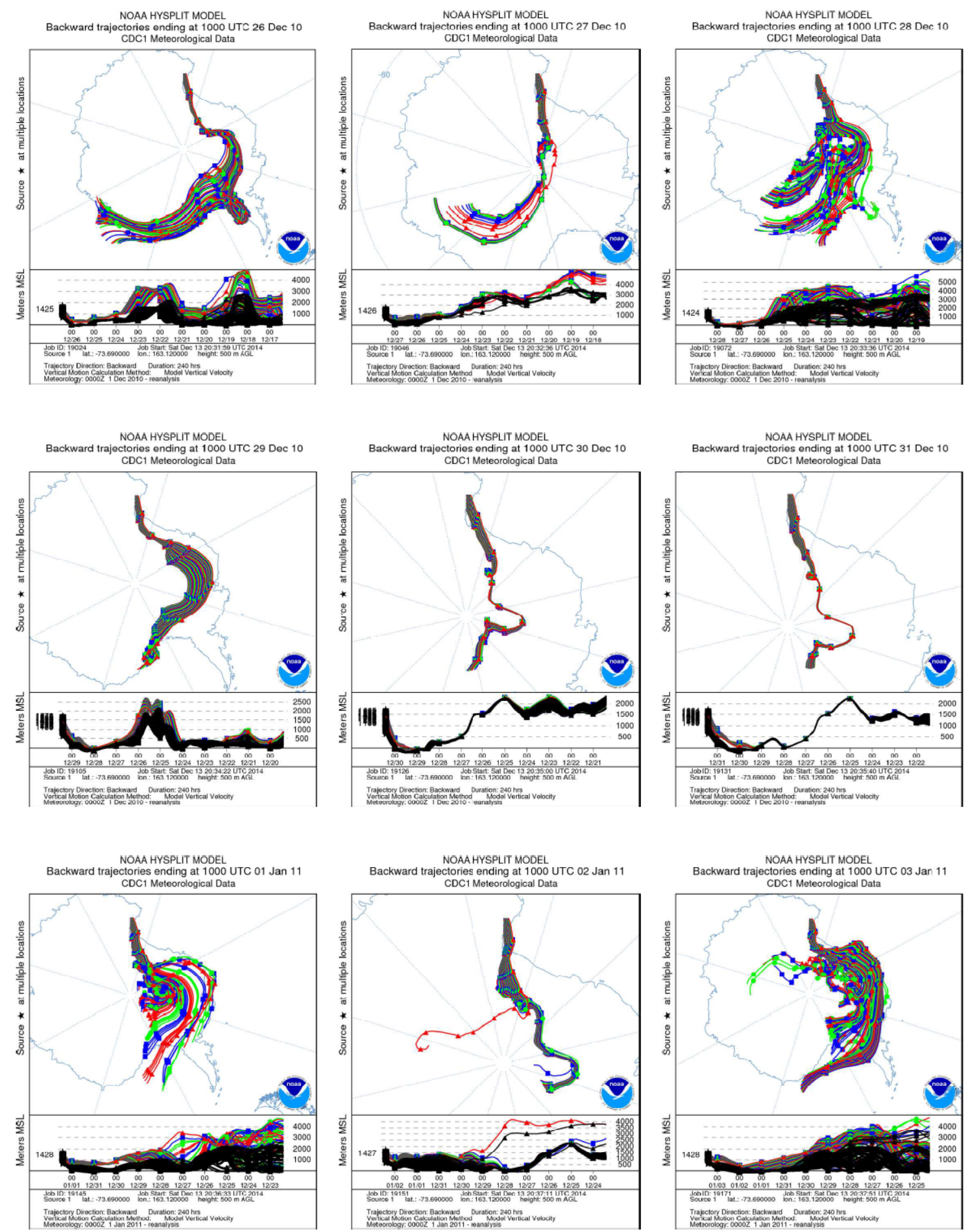

Figure S4. continued 

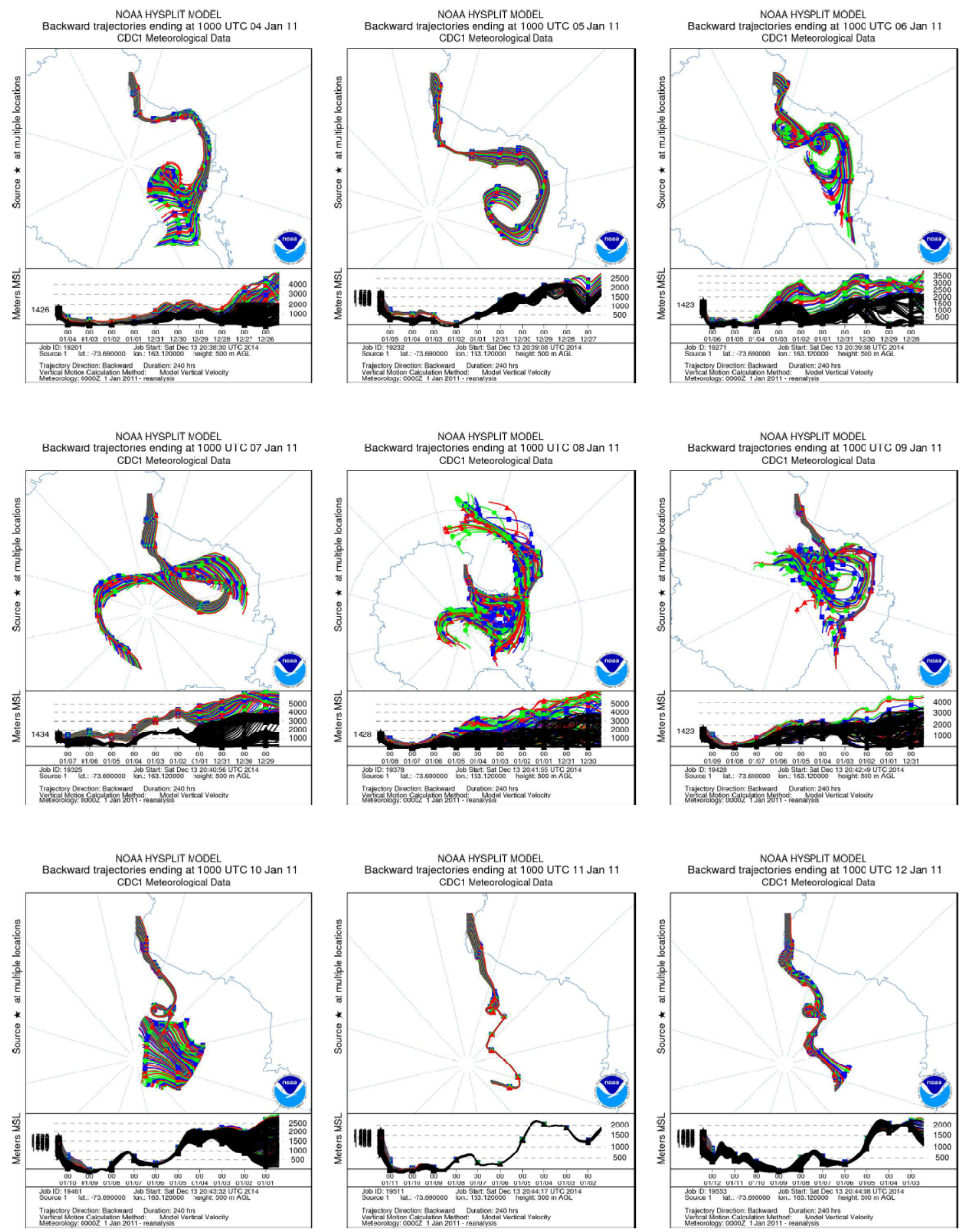

Figure S4. continued 

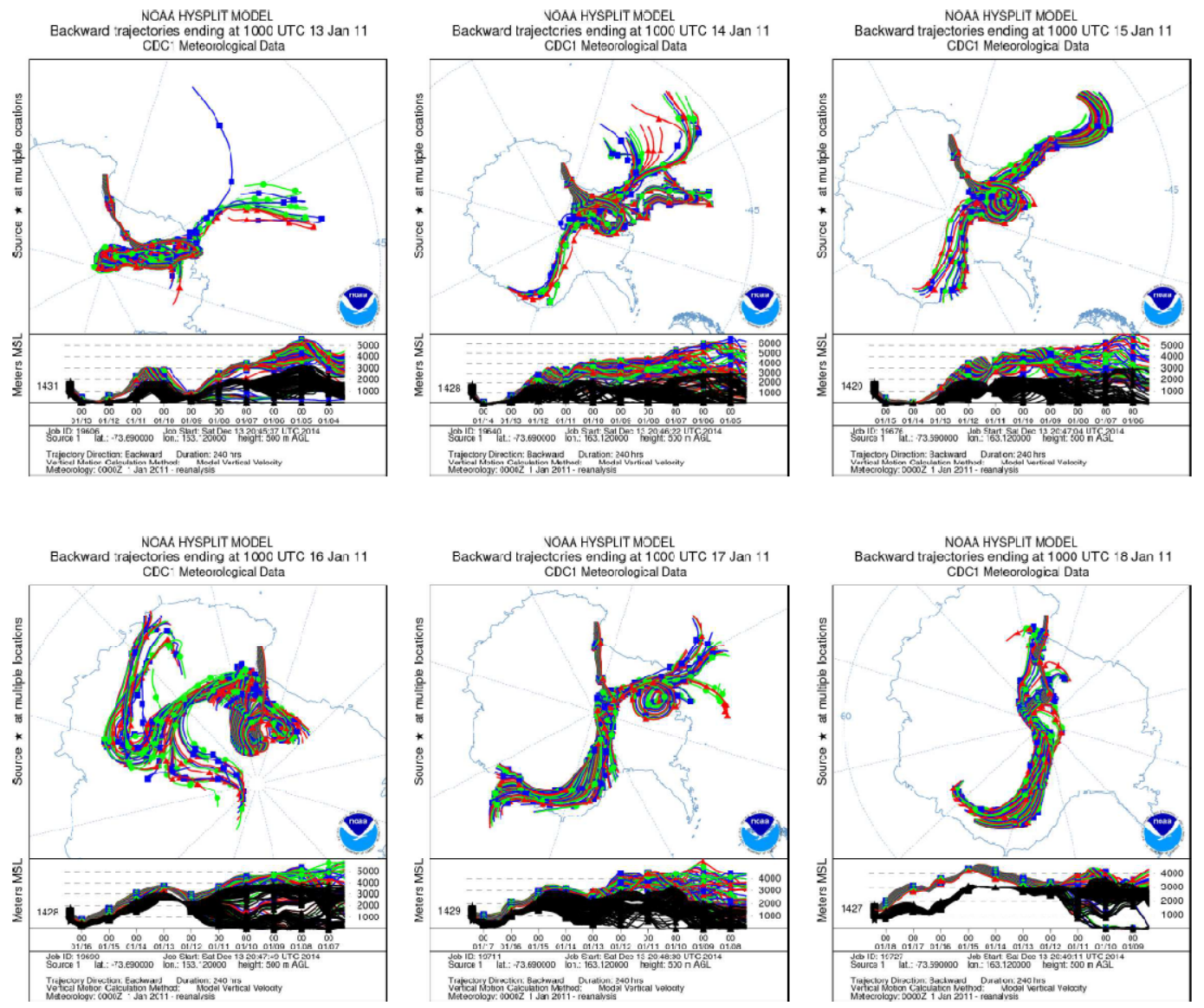

Figure S4. continued 

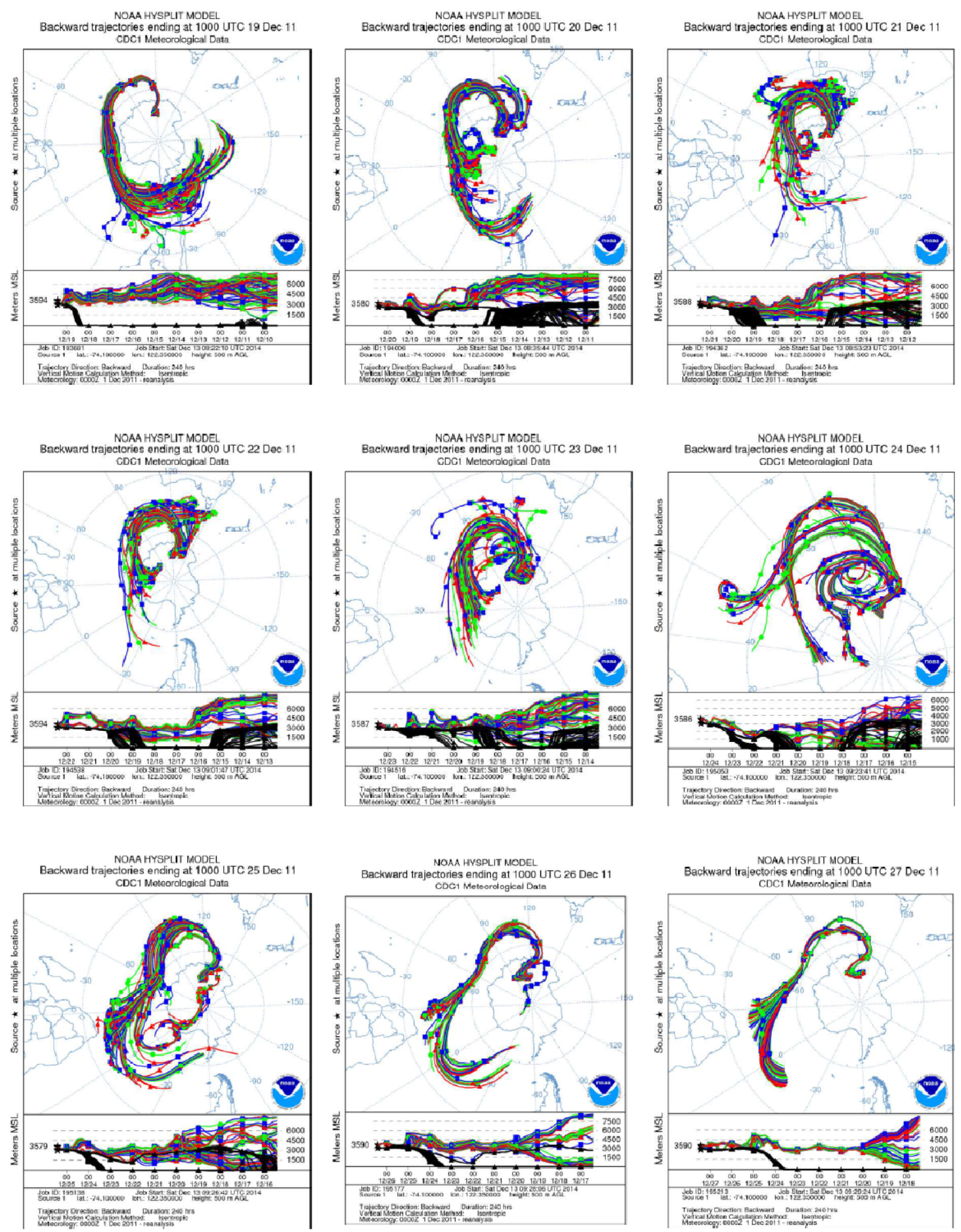

Figure S5. Matrix back-trajectories computed for each 24-h sampling at $500 \mathrm{~m}$ agl at the ItalianFrench base Dome C (DC) $19^{\text {th }}$ December 2011 to $28^{\text {th }}$ January 2012. Study of the horizontal stability of HYSPLIT model varying the source position of one degree of latitude and longitude from the real coordinates of source. 

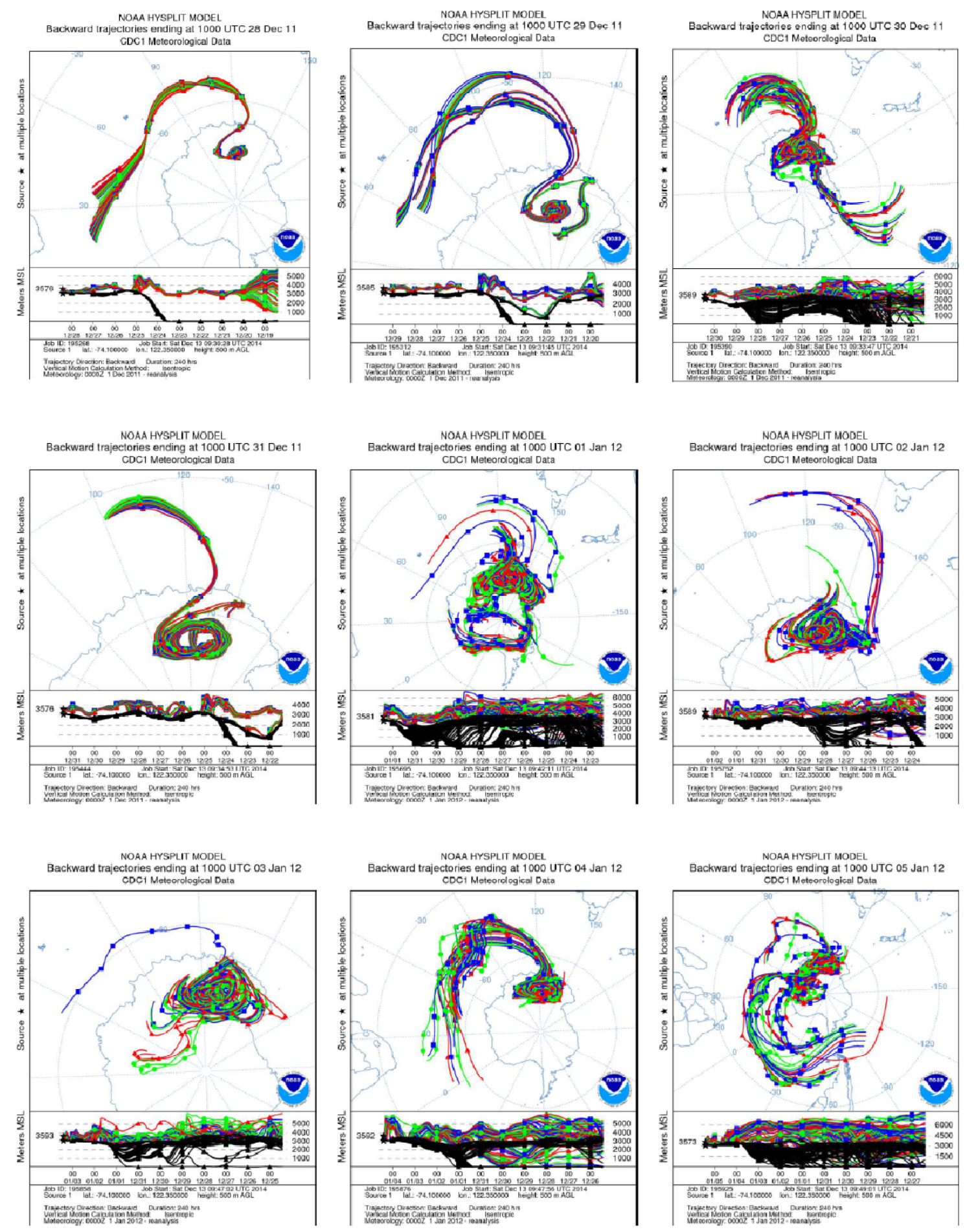

Figure S5. continued 

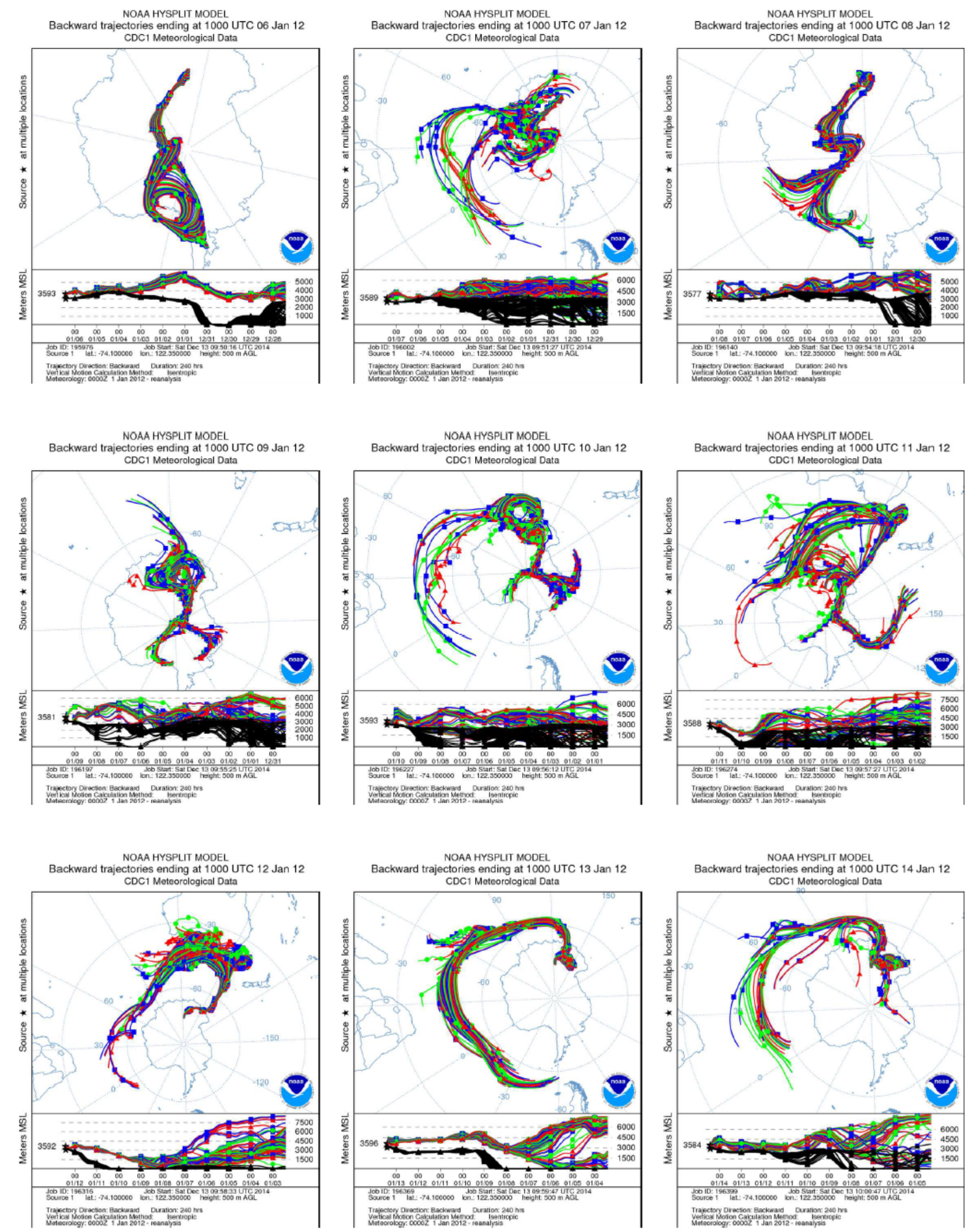

Figure S5. continued 

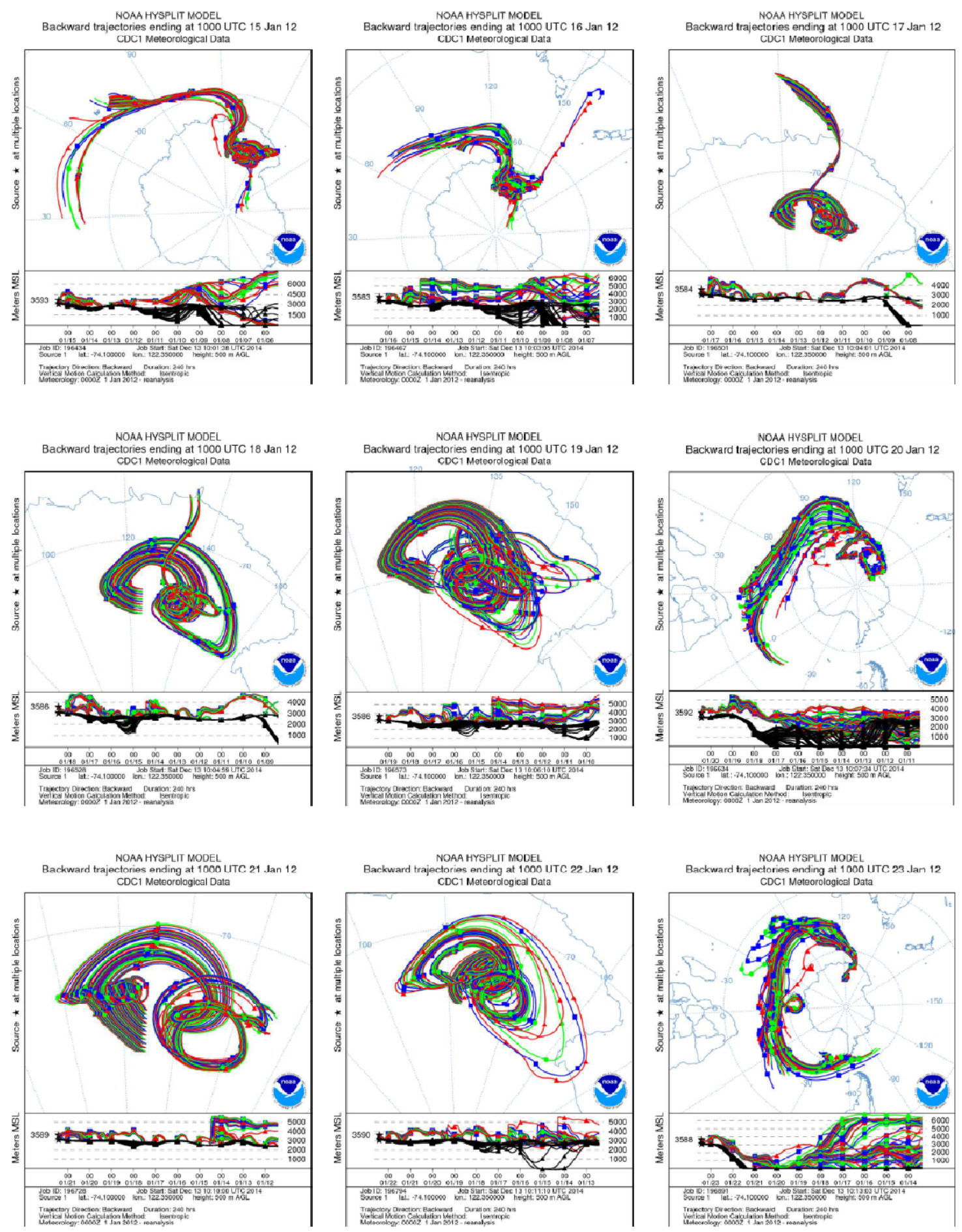

Figure S5. continued 

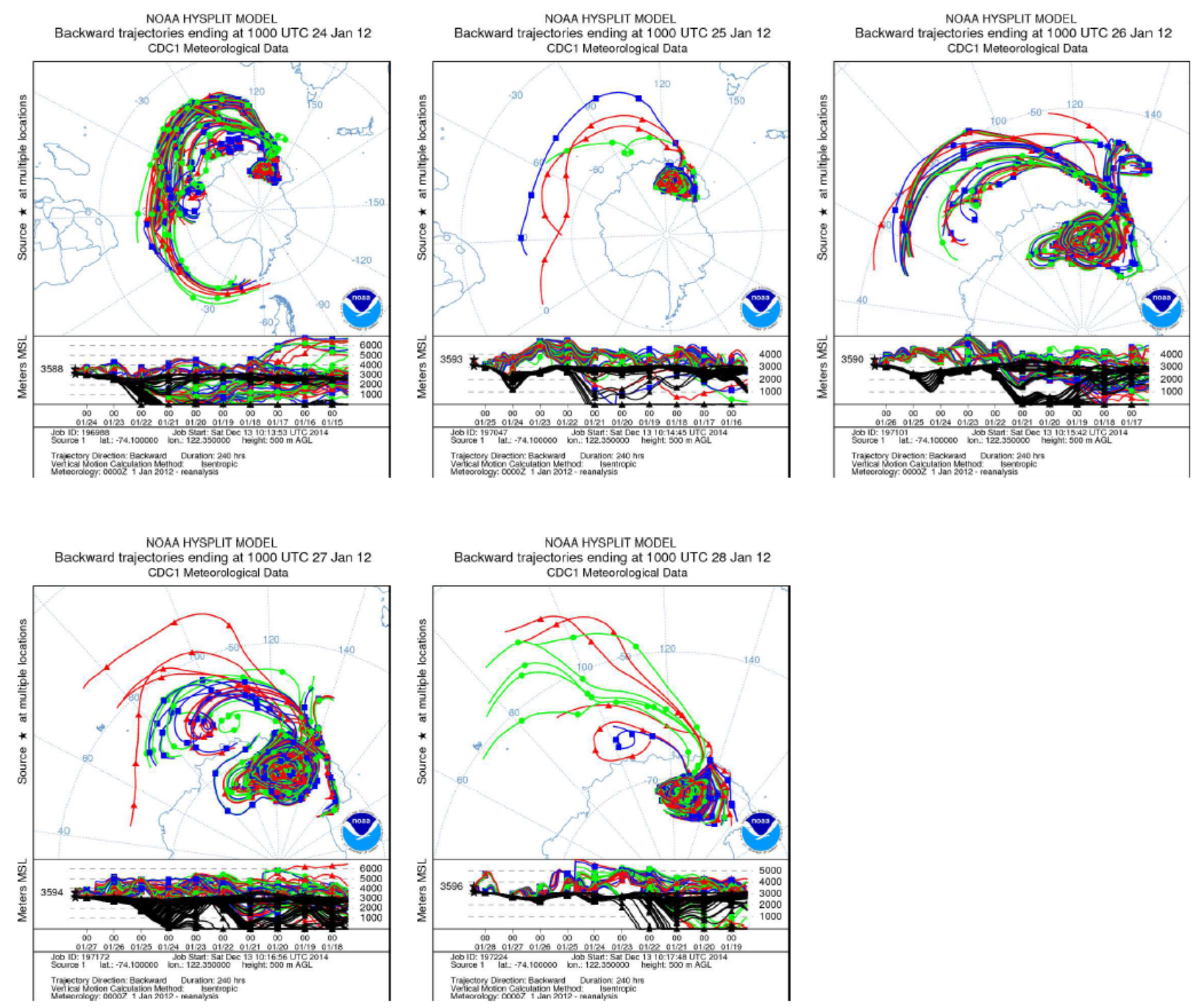

Figure S5. continued 

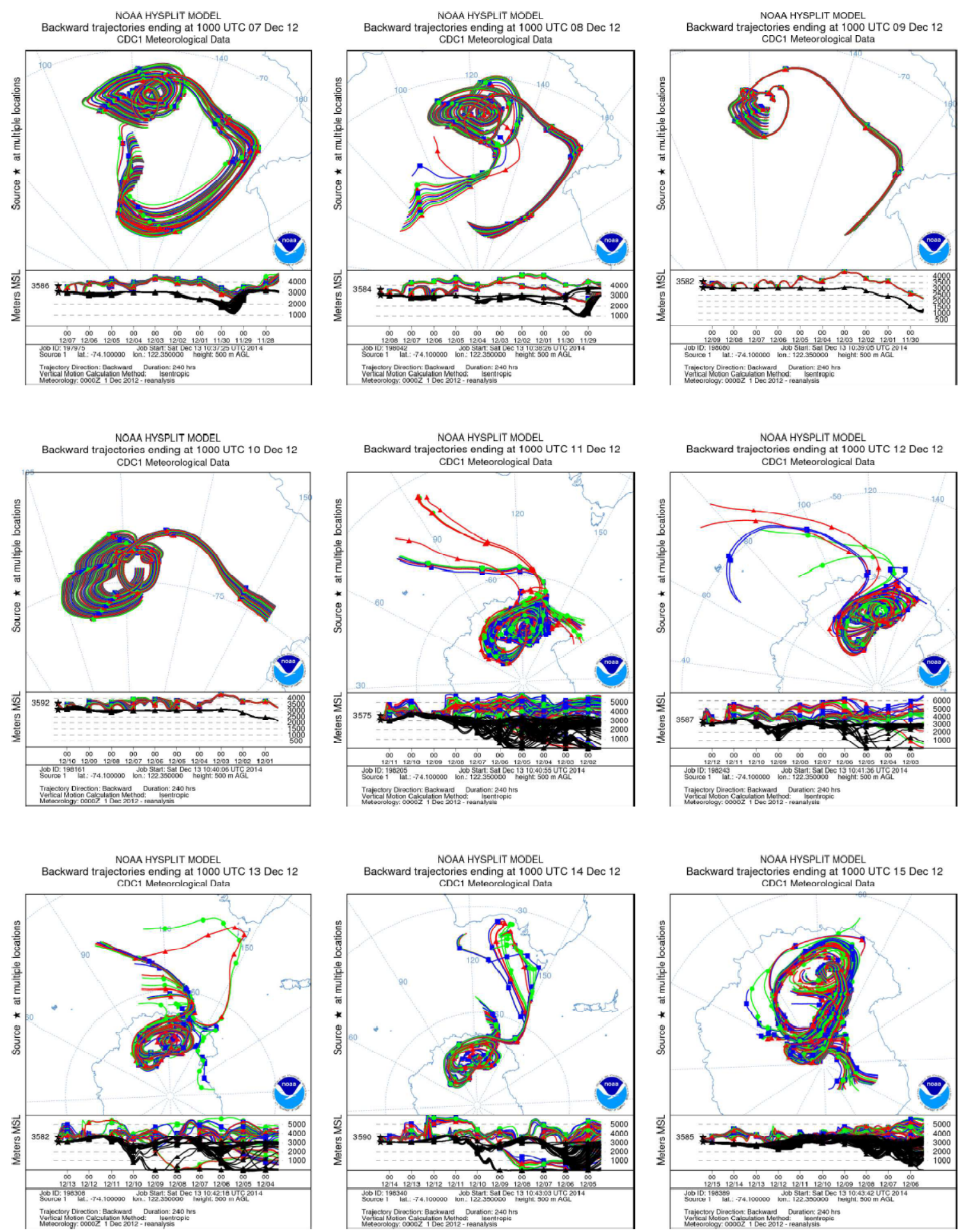

Figure S6. Matrix back-trajectories computed for each 24-h sampling at $500 \mathrm{~m}$ agl at the ItalianFrench base Dome C (DC) from $07^{\text {th }}$ December 2012 to $26^{\text {th }}$ January 2013. Study of the horizontal stability of HYSPLIT model varying the source position of one degree of latitude and longitude from the real coordinates of source. 

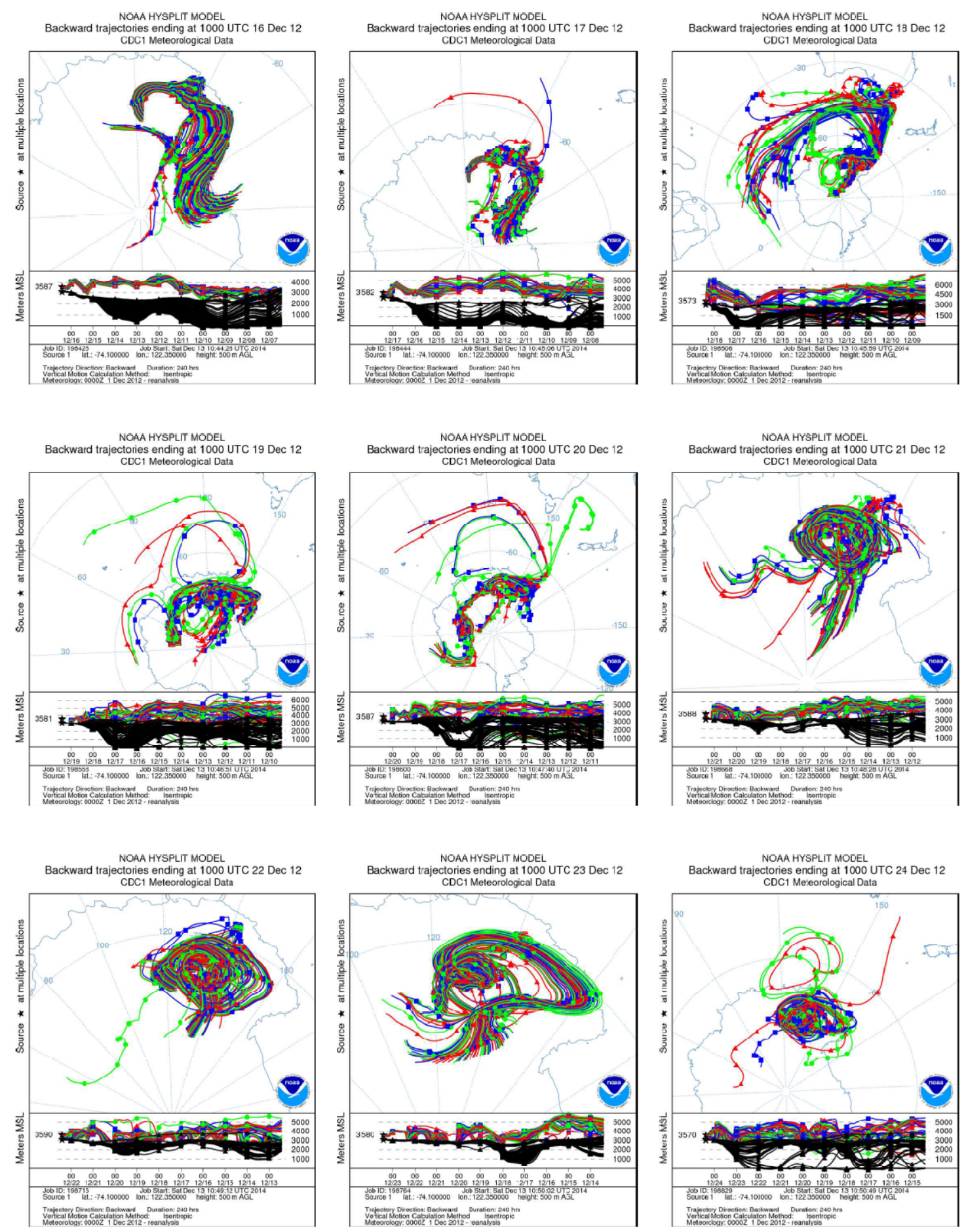

Figure S6. continued 

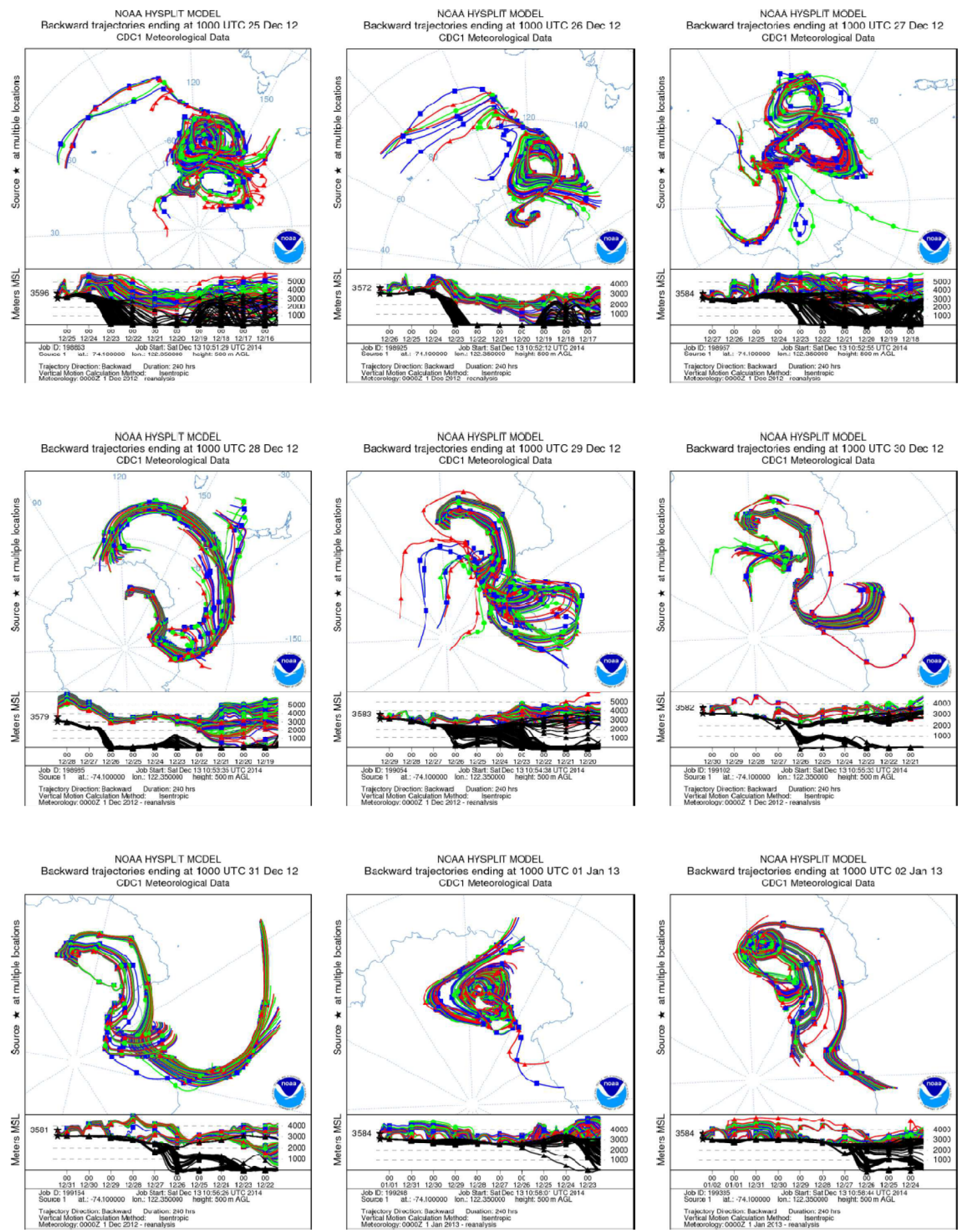

Figure S6. continued 

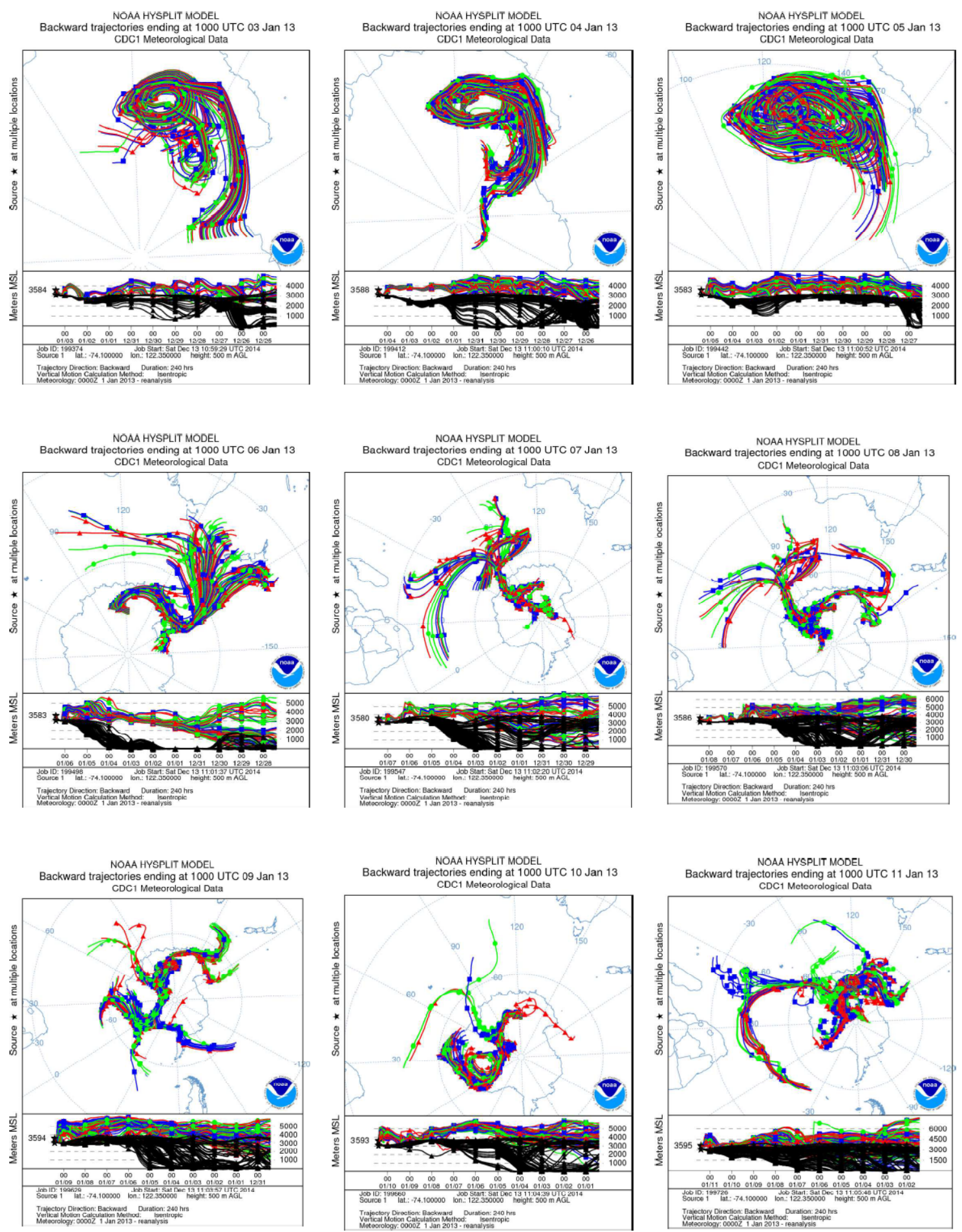

Figure S6. continued 

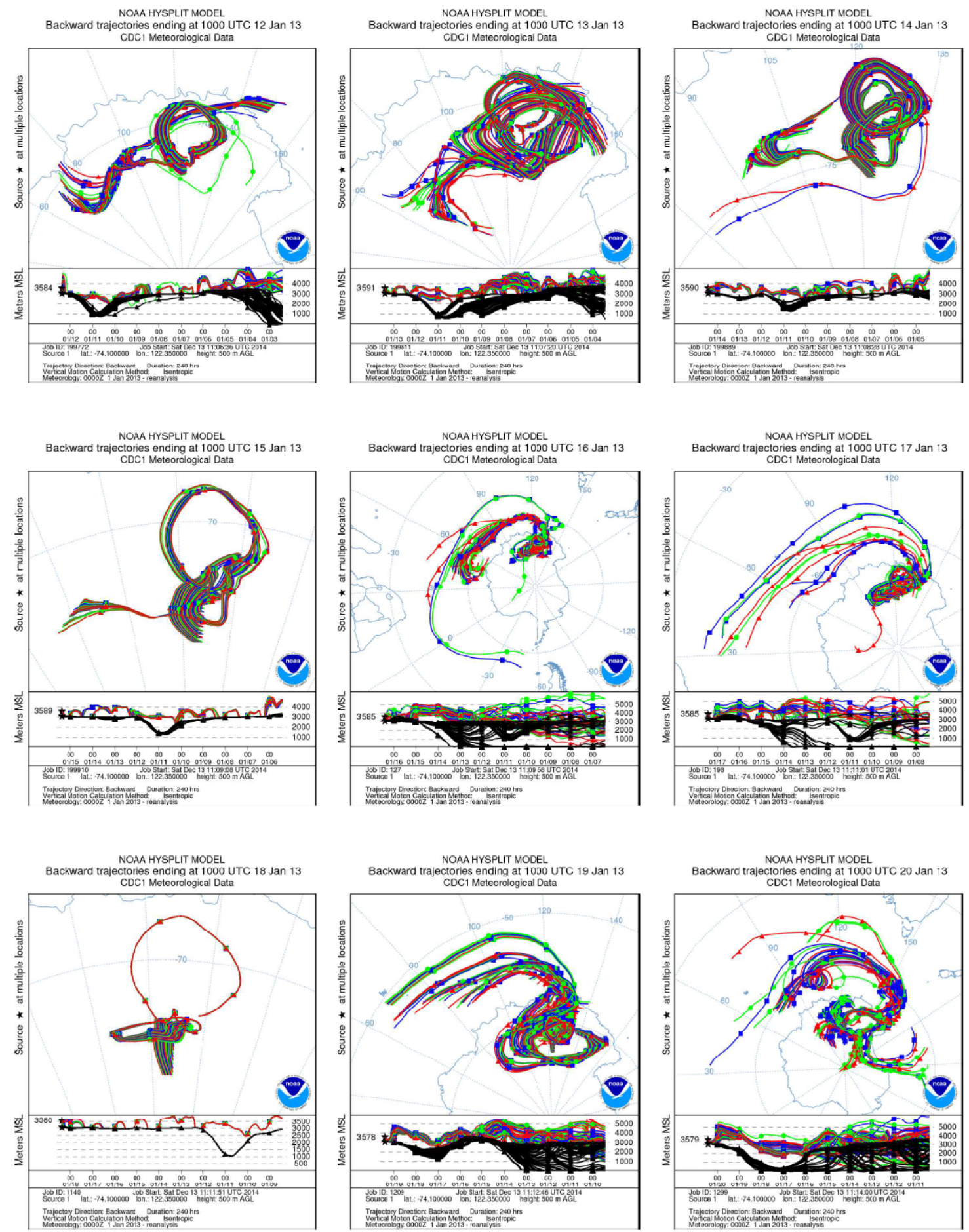

Figure S6. continued 

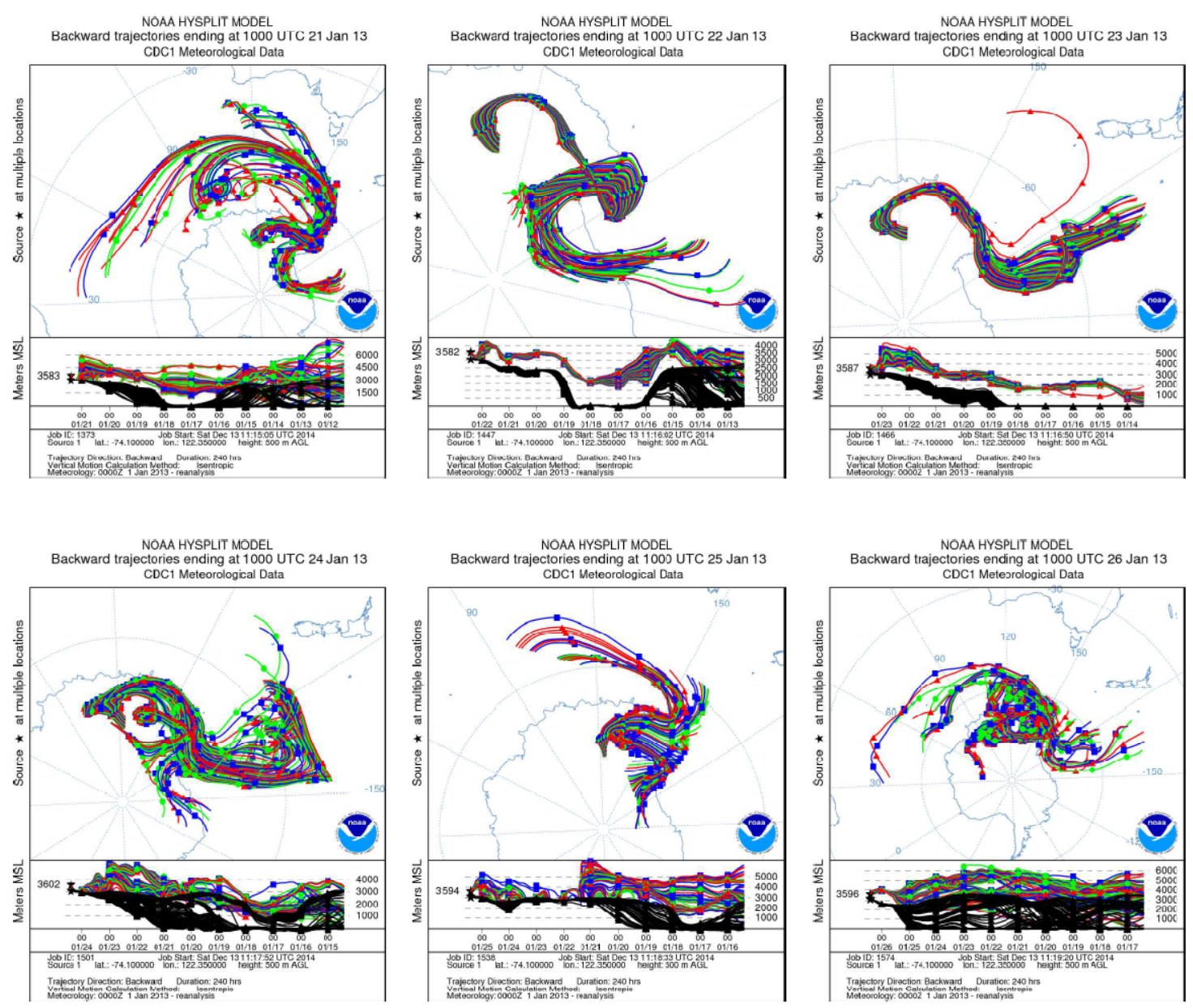

Figure S6. continued 


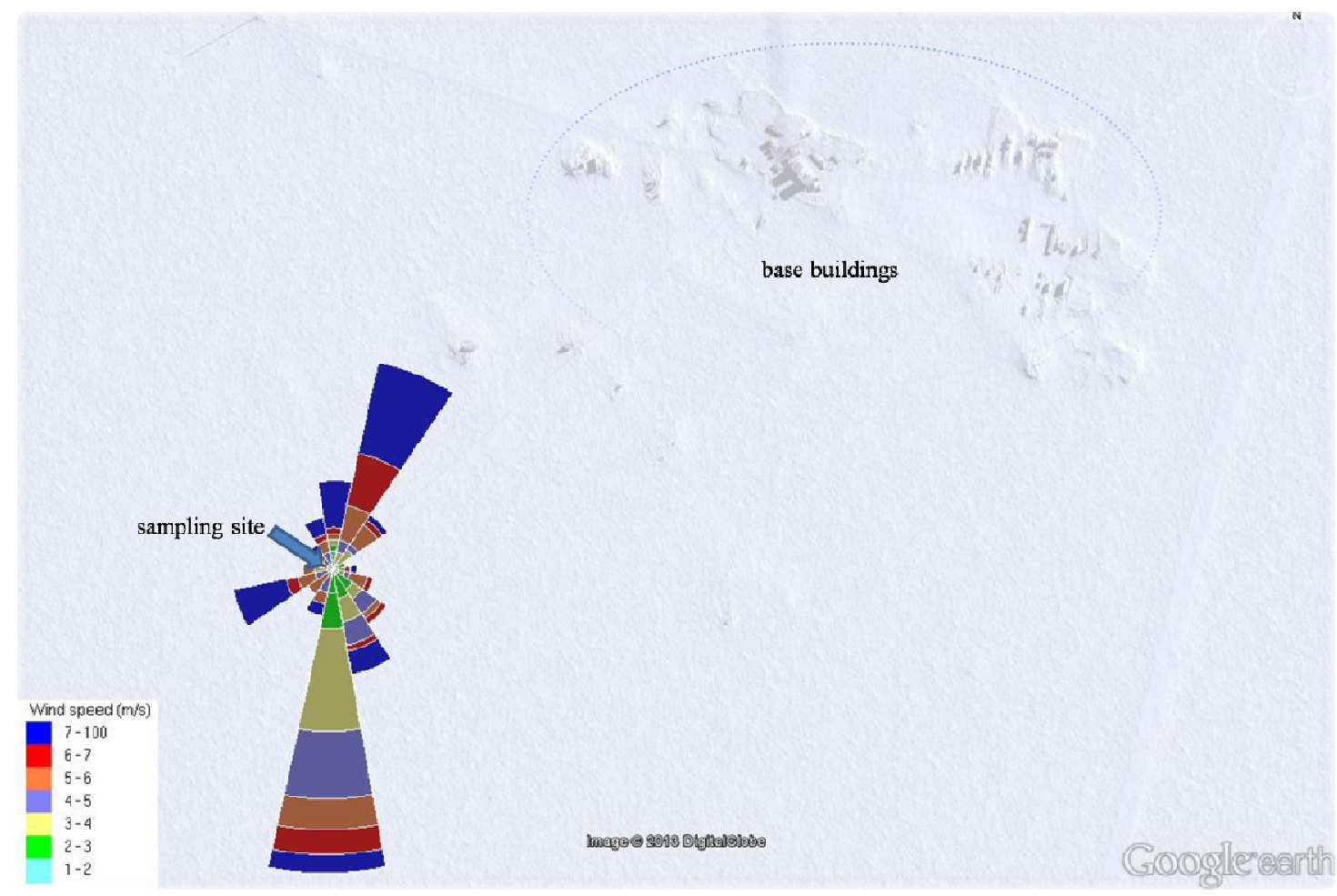

Figure S7. Wind rose of the sample collected from 27 December to 06 January at the Italian-French base "Concordia Station" (Dome C) during the summer in Antarctica 2012-13. 


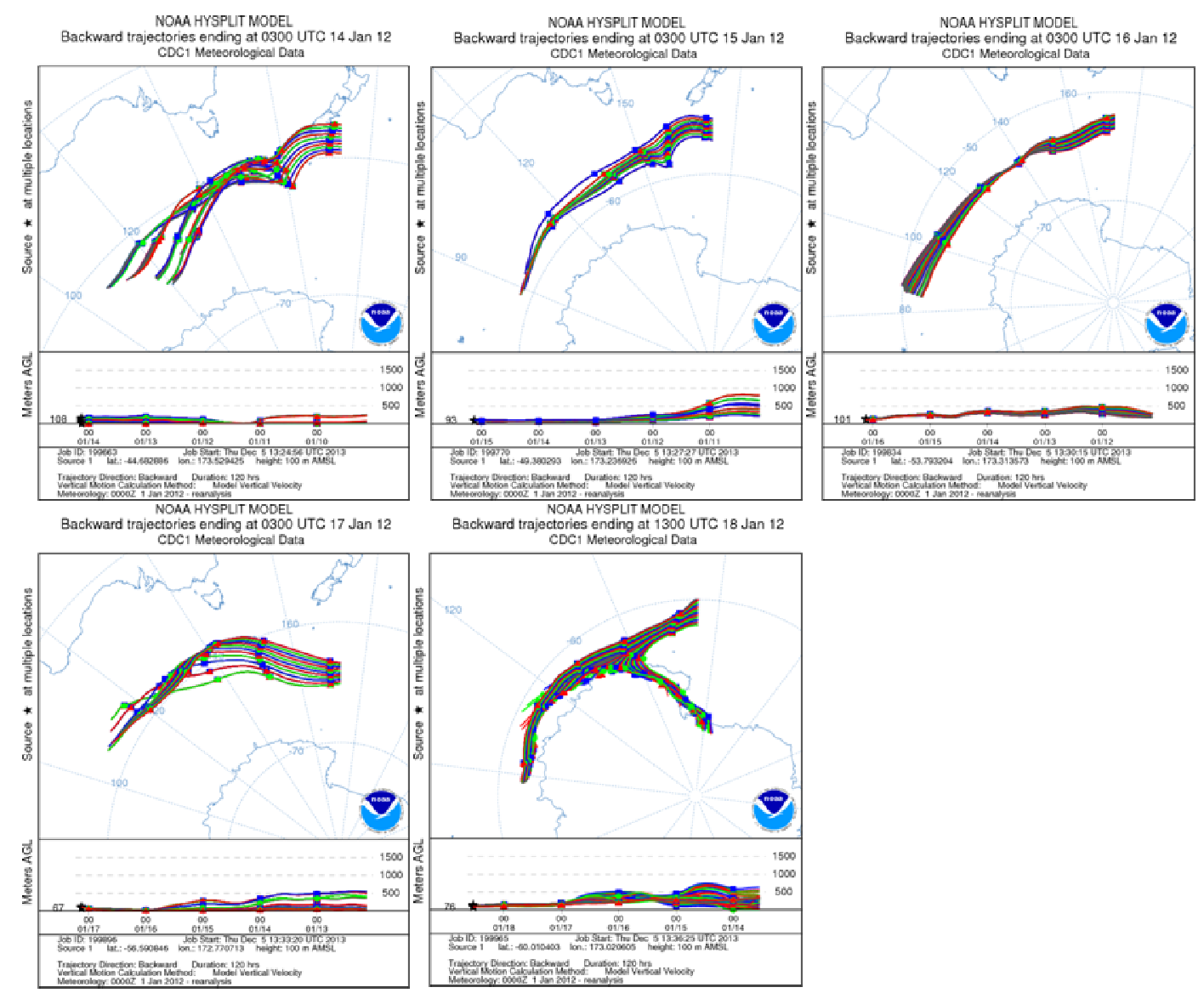

Figure S8A. 5-day back-trajectories of the first sample (from 13 to 18 January) collected during the oceanographic cruise on the R/V Italica during the summer of 2011-12 on the Southern Ocean. The trajectories were computed for each 24-h sampling using a vertical velocity model at $100 \mathrm{~m}$ above sea level. 


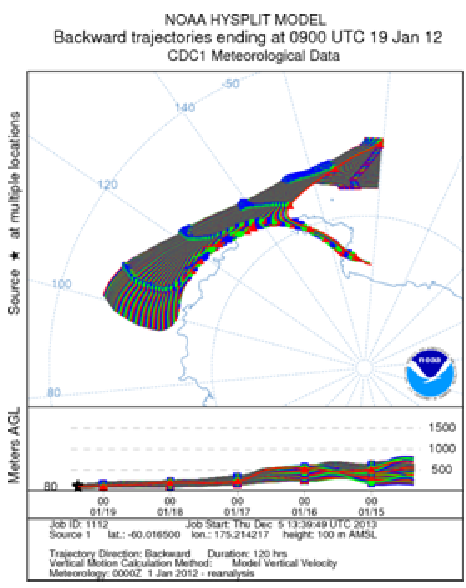

Backward traiectoma HYSPUT MODEL
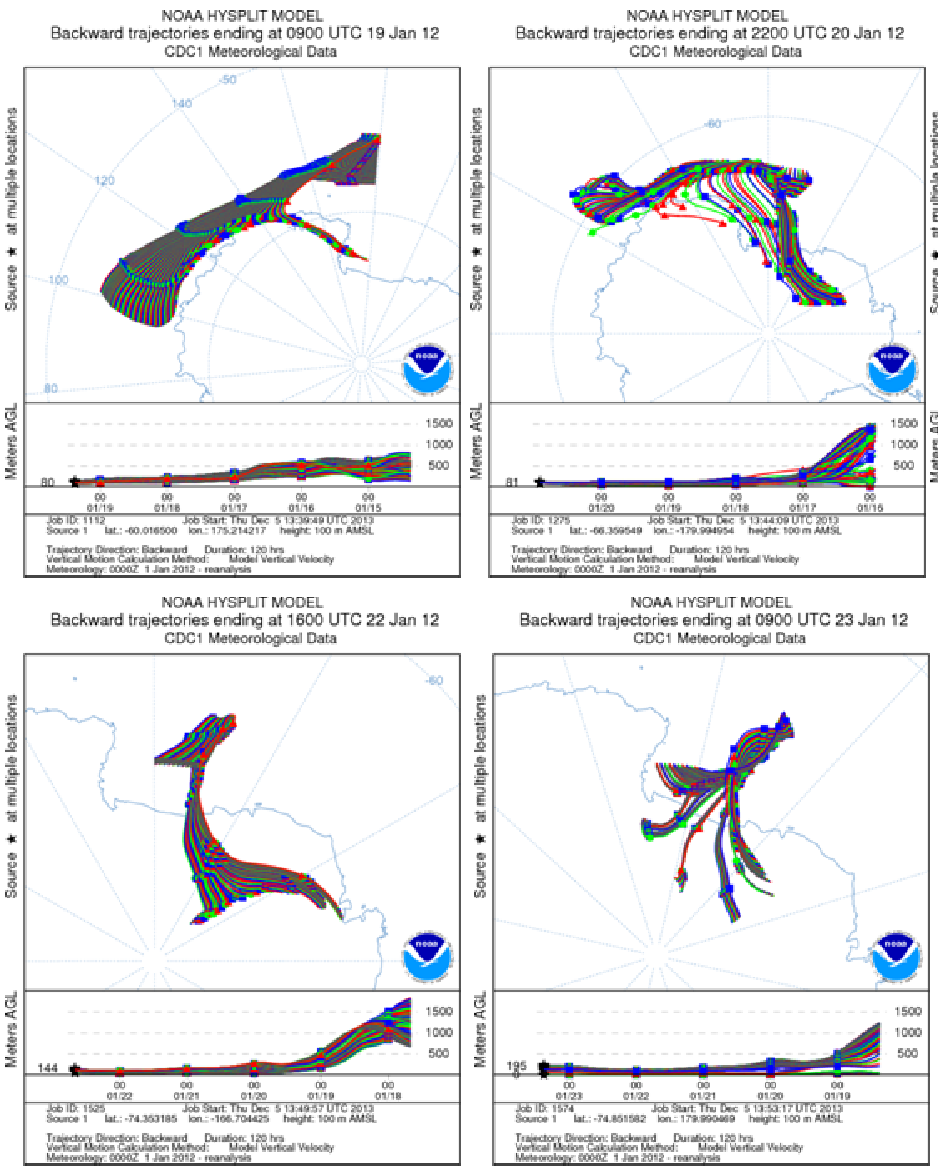

NOAA HYSPUT MODEL
Backward trajectories ending at 0900 UTC 23 Jan 12 CDC1 Meteorological Dat

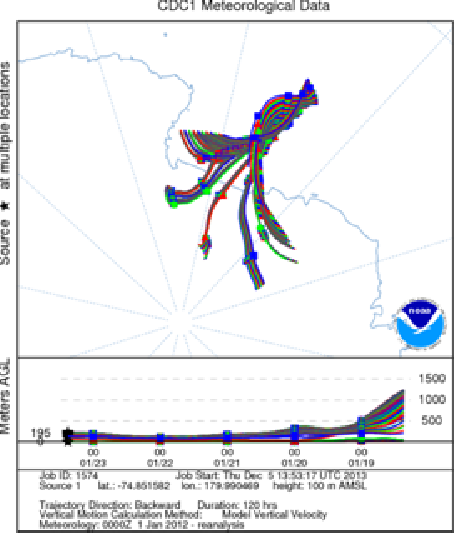

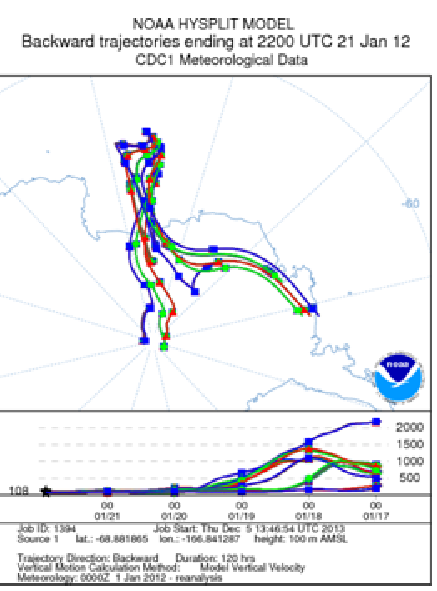

Figure S8B. 5-day back-trajectories of the second sample (from 18 to 23 January) collected during the oceanographic cruise on the R/V Italica during the summer of 2011-12 on the Southern Ocean. The trajectories were computed for each $24-\mathrm{h}$ sampling using a vertical velocity model at $100 \mathrm{~m}$ above sea level. 

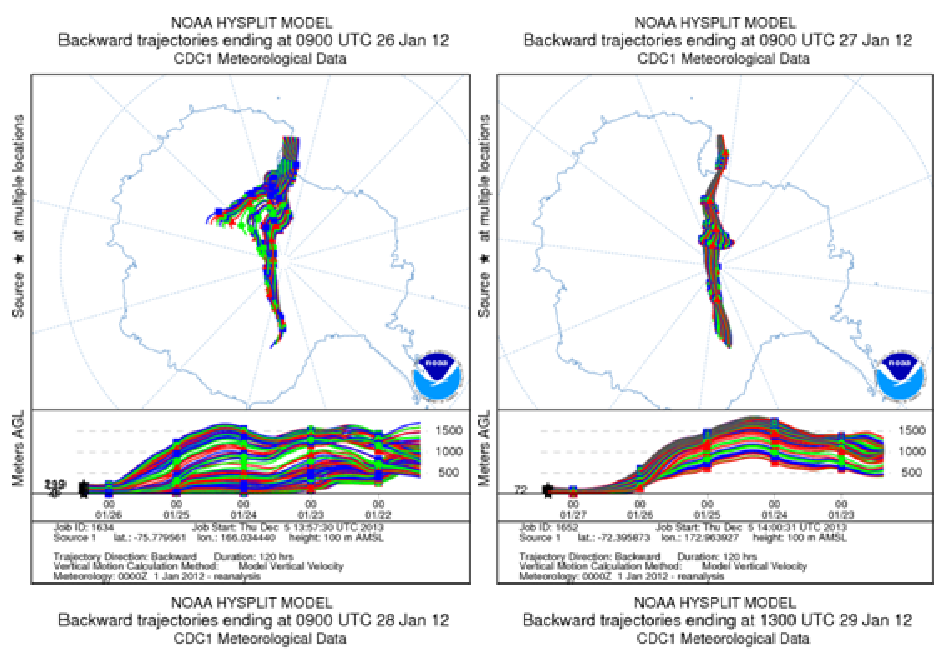

NaAckward trajectories enSPIing at MODEL 1300 UTC 29 Jan 12
CDC1 Meteorological Data
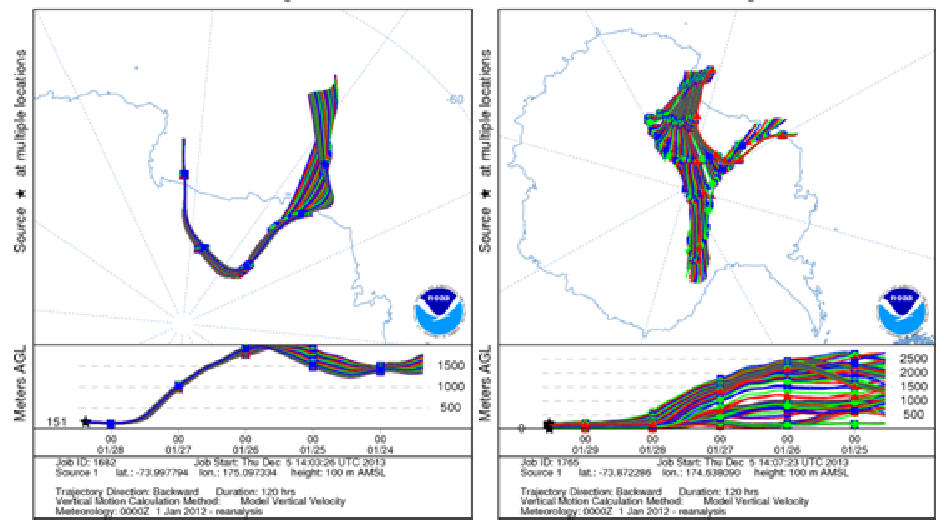

Figure S8C. 5-day back-trajectories of the third sample (from 25 to 29 January) collected during the oceanographic cruise on the R/V Italica during the summer of 2011-12 on the Southern Ocean.. The trajectories were computed for each $24-\mathrm{h}$ sampling using a vertical velocity model at $100 \mathrm{~m}$ above sea level. 

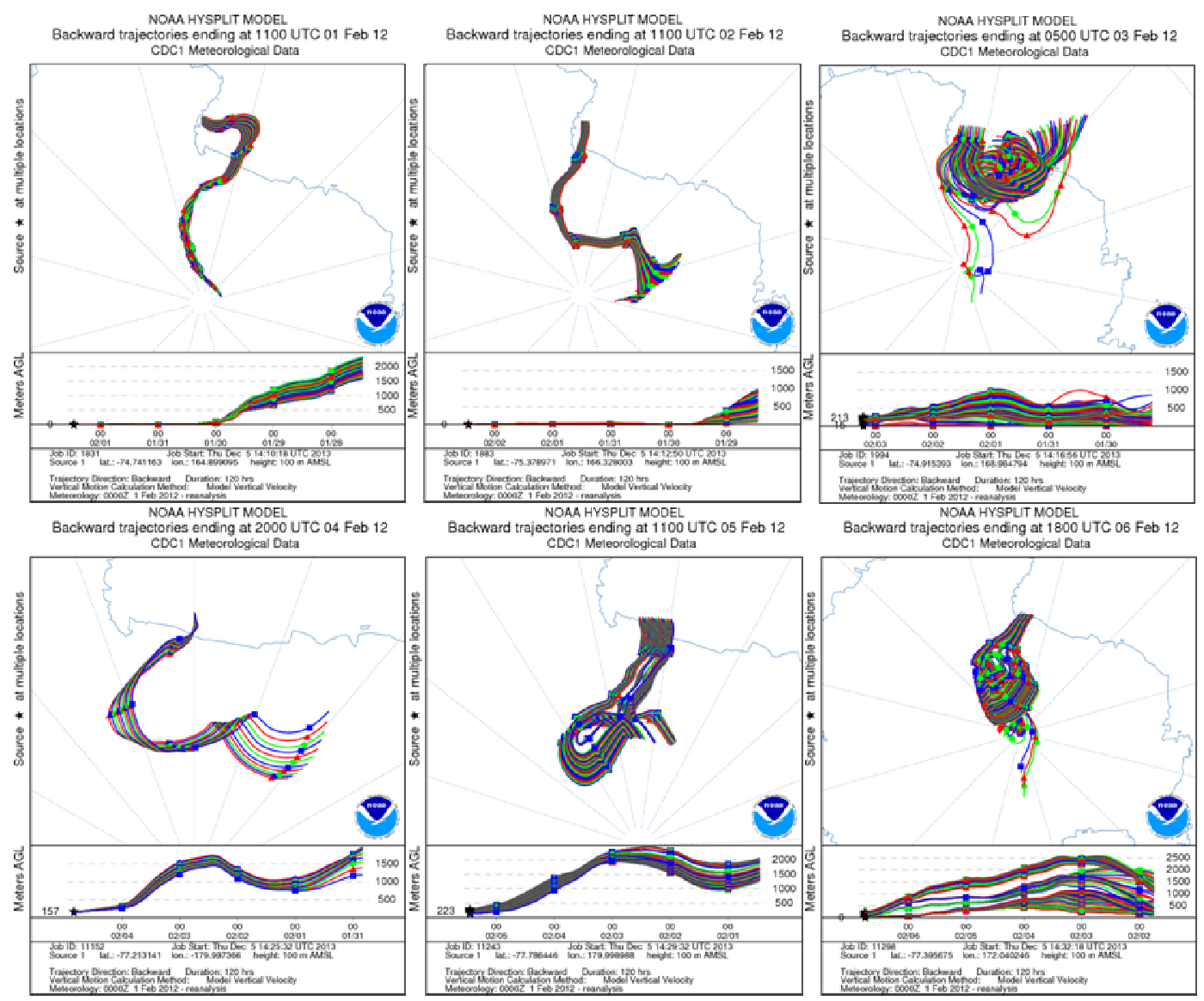

Figure S8D. 5-day back-trajectories of the fourth sample (from 31 January to 6 February) collected during the oceanographic cruise on the R/V Italica during the summer of 2011-12 on the Southern Ocean. The trajectories were computed for each 24 -h sampling using a vertical velocity model at $100 \mathrm{~m}$ above sea level. 


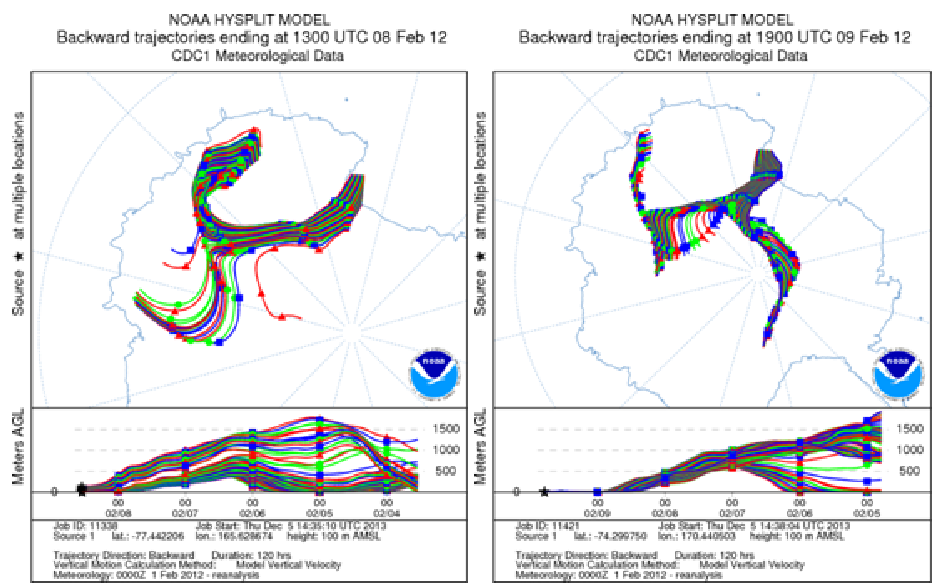

Figure S8E. 5-day back-trajectories of the fifth sample (from 7 to 9 February) collected during the oceanographic cruise on the R/V Italica during the summer of 2011-12 on the Southern Ocean. The trajectories were computed for each $24-\mathrm{h}$ sampling using a vertical velocity model at $100 \mathrm{~m}$ above sea level.

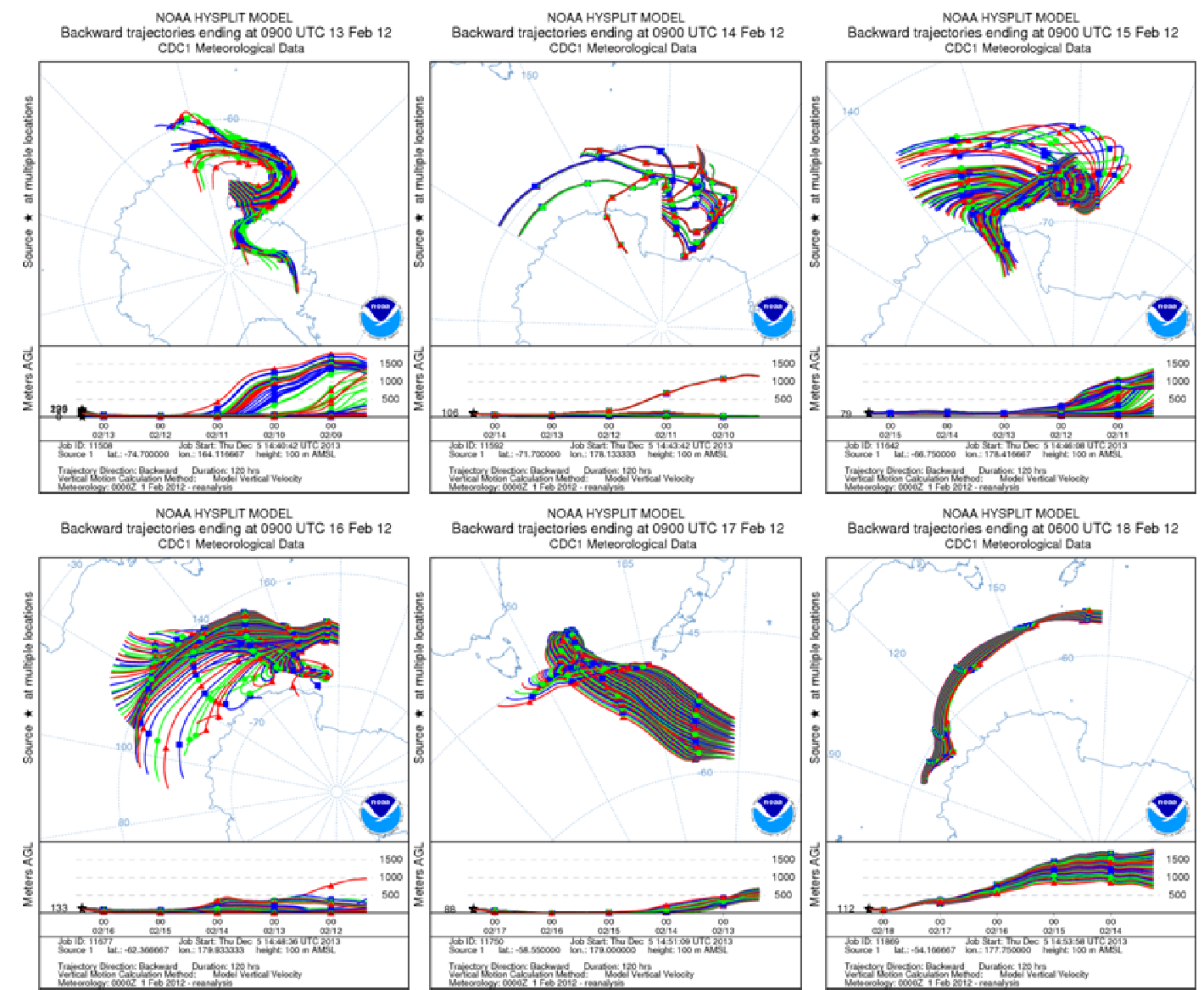

Figure S8F. 5-day back-trajectories of the sixth sample (from 13 to 18 February) collected during the oceanographic cruise on the R/V Italica during the summer of 2011-12 on the Southern Ocean.. The trajectories were computed for each 24-h sampling using a vertical velocity model at $100 \mathrm{~m}$ above sea level. 


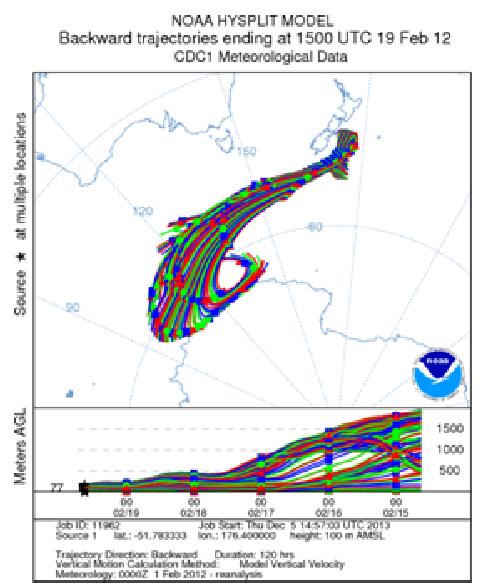

Figure S8G. 5-day back-trajectories of the seventh sample (from 18 to 19 February) collected during the oceanographic cruise on the R/V Italica during the summer of 2011-12 on the Southern Ocean. The trajectories were computed for each $24-\mathrm{h}$ sampling using a vertical velocity model at $100 \mathrm{~m}$ above sea level. 